\title{
Effect of water column light gradient on phytoplankton fluorescence transients
}

\author{
M. Raateoja ${ }^{1,4, *}$, B. G. Mitchell ${ }^{2}$, H. Wang ${ }^{2}$, E. Olivo ${ }^{3}$ \\ ${ }^{1}$ Finnish Institute of Marine Research, 00560 Helsinki, Finland \\ ${ }^{2}$ Scripps Institution of Oceanography, University of California, San Diego, La Jolla, California 92093-0218, USA \\ ${ }^{3}$ Université Pierre et Marie Curie, 75005 Paris, France \\ ${ }^{4}$ Present address: SYKE Marine Centre, 00251 Helsinki, Finland
}

\begin{abstract}
The light management of phytoplankton can be assessed in situ on time scales shorter than those of the non-photochemical fluorescence quenching $\left(\mathrm{q}_{\mathrm{n}}\right)$ mechanisms. We adopted fast repetition rate fluorometry to water column studies in the northwest Pacific Ocean and its adjacent shelf seas. Near-surface depression of the photochemical energy conversion efficiency (PECE) (effective $\mathrm{F}_{\mathrm{q}}{ }^{\prime} / \mathrm{F}_{\mathrm{m}}{ }^{\prime}$ and maximum $\mathrm{F}_{\mathrm{v}}{ }^{\prime} / \mathrm{F}_{\mathrm{m}}{ }^{\prime} ; \mathrm{F}_{\mathrm{q}}{ }^{\prime}=\mathrm{F}_{\mathrm{m}}{ }^{\prime}-\mathrm{F}^{\prime}, \mathrm{F}_{\mathrm{v}}{ }^{\prime}=\mathrm{F}_{\mathrm{m}}{ }^{\prime}-\mathrm{F}_{\mathrm{o}}{ }^{\prime} ; \mathrm{F}_{\mathrm{q}}{ }^{\prime}$ and $\mathrm{F}_{\mathrm{v}}{ }^{\prime}$ are variable fluorescence yields in the light, $\mathrm{F}_{\mathrm{v}}{ }^{\prime}$ is that with maximum photochemical quenching; fluorescence yields in the light: $\mathrm{F}_{\mathrm{m}}{ }^{\prime}$ maximum, $\mathrm{F}^{\prime}$ steady-state, and $\mathrm{F}_{\mathrm{o}}{ }^{\prime}$ minimum) defined specific zones according to whether PECE was depressed by photochemistry (relaxation of photochemical quenching, $\mathrm{q}_{\mathrm{p}}$ ) or photoprotection/photoinhibition (increase of $\mathrm{q}_{\mathrm{n}}$ ). $\mathrm{q}_{\mathrm{p}}$ seemed to be the main factor depressing PECE, and the depressing effect of $\mathrm{q}_{\mathrm{p}}$ on PECE also extended to considerably deeper depths than that of $q_{n}$. When moving towards the surface, the $q_{n}$ effect overrode the $q_{p}$ effect on the PECE decrease at depths of 8 to $13 \mathrm{~m}$, depending on the station. The vertical trends of $\mathrm{F}_{\mathrm{q}}{ }^{\prime} / \mathrm{F}_{\mathrm{m}}{ }^{\prime}$ and $\mathrm{F}_{\mathrm{v}}{ }^{\prime} / \mathrm{F}_{\mathrm{m}}{ }^{\prime}$ were modelled according to a typical P-E (photosynthesis-irradiance) dependence to supplement the ${ }^{14} \mathrm{C}$-based $\mathrm{P}-\mathrm{E}$ data. $\mathrm{E}\left(\mathrm{F}_{\mathrm{q}}{ }^{\prime} / \mathrm{F}_{\mathrm{m}}{ }^{\prime}\right)$ and $\mathrm{E}\left(\mathrm{F}_{\mathrm{v}}{ }^{\prime} / \mathrm{F}_{\mathrm{m}}{ }^{\prime}\right)$ were the light levels at which the vertical trends of $\mathrm{F}_{\mathrm{q}}{ }^{\prime} / \mathrm{F}_{\mathrm{m}}{ }^{\prime}$ and $\mathrm{F}_{\mathrm{v}}{ }^{\prime} / \mathrm{F}_{\mathrm{m}}{ }^{\prime}$, respectively, started to decrease. Although the nutrient regime is the main controller of primary photochemistry in general, the ambient light also becomes the controlling factor on PECE whenever the light level rises above $\mathrm{E}\left(\mathrm{F}_{\mathrm{q}}{ }^{\prime} / \mathrm{F}_{\mathrm{m}}{ }^{\prime}\right)$. At $\mathrm{E}\left(\mathrm{F}_{\mathrm{v}}{ }^{\prime} / \mathrm{F}_{\mathrm{m}}{ }^{\prime}\right)$, light ultimately overrides the effect of the nutrient status on PECE. $\mathrm{E}\left(\mathrm{F}_{\mathrm{v}}{ }^{\prime} / \mathrm{F}_{\mathrm{m}}{ }^{\prime}\right)$ also marks the light level at which the photoprotective measures first become necessary. This level is close to the onset of the plateau phase producing the ${ }^{14} \mathrm{C}$-based light-saturated photosynthetic rate $\mathrm{P}_{\max }$.
\end{abstract}

KEY WORDS: Pacific Ocean · Phytoplankton · FRR · Fluorescence · Quenching · Photochemical

\section{INTRODUCTION}

Phytoplankton inhabiting the surface layer face rapid and pronounced variations in the ambient light (Cullen \& Lewis 1988). Light fluctuates on temporal scales from the effect of waving of the order of fractions of a second, to a diurnal scale of a number of hours. Vertically this fluctuation presents an exponentially waning pattern that also includes a spectral component. This poses a real challenge to the photosynthetic machinery as to how to adjust itself for optimal functioning. Light reactions comprise that part of the machinery having to cope with the highly variable nature of the underwater light.

The light reactions convert light energy to oxidation-reduction energy in order to perform 2 photo- chemical charge separations that push electrons forward in the electron transport chain. However, the electron transport rate is not directly proportional to the ambient light flux, at least at the irradiance levels saturating the photosynthesis (e.g. Barranguet \& Kronkamp 2000, Figueroa et al. 2003, Raateoja 2004, Fujiki et al. 2007). Deviation from linear dependence stems from e.g. photoacclimative measures: strategies including changes in the antenna size of photosystem II (PSII) or the changes in the number of PSIIs - help phytoplankton to cope with the changing light environment (Dubinsky et al. 1986, Moore et al. 2006).

There exists an array of biophysical mechanisms whose functioning results in a decreased photochemical energy conversion efficiency (PECE) of PSII. PECE is quantified by the fluorescence induction based para- 
meters $\mathrm{F}_{\mathrm{q}}{ }^{\prime} / \mathrm{F}_{\mathrm{m}}{ }^{\prime}$ (effective) and $\mathrm{F}_{\mathrm{v}}{ }^{\prime} / \mathrm{F}_{\mathrm{m}}{ }^{\prime}$ (maximum) (see Table 1 for abbreviation). These biophysical mechanisms mainly fine-tune the photosynthetic machinery against the variations in the ambient light, but some of them reflect the primary photochemistry or the photodamage incurred. The common denominator for these mechanisms is that they can be monitored by fluorescence induction. These are termed either photochemical ( $\mathrm{q}_{\mathrm{p}}$ ) (Bradbury \& Baker 1984, Genty et al. 1989) or non-photochemical $\left(\mathrm{q}_{\mathrm{n}}\right)$ fluorescence quenching (Bradbury \& Baker 1981, Horton \& Hague 1988).

Light-driven PECE decreases can thus be caused both by qp (Weis \& Berry 1987, Falkowski \& Kolber 1993) and $q_{n}$ (Genty et al. 1990, Vassiliev et al. 1994, Gorbunov et al. 2001). Typically they work simultaneously, their effect thus being additive. $\mathrm{q}_{\mathrm{p}}$ is an index of the redox state of the quinone $A\left(Q_{A}\right)$ pool, i.e. the openness of the reaction centre II (RCII) pool, to which PECE is proportional (Falkowski \& Kolber 1993). This quenching factor is due to photochemistry, not to photoprotection. Mathematically, $\mathrm{q}_{\mathrm{p}}$ is best described by the PSII efficiency factor $\left(\mathrm{F}_{\mathrm{q}}{ }^{\prime} / \mathrm{F}_{\mathrm{v}}{ }^{\prime}=\left(\mathrm{F}_{\mathrm{m}}{ }^{\prime}-\mathrm{F}^{\prime}\right) /\left(\mathrm{F}_{\mathrm{m}}{ }^{\prime}-\mathrm{F}_{\mathrm{o}}{ }^{\prime}\right)\right.$
(Oxborough 2004). This formulation tells how large a part of the maximum PECE is actually realized in situ.

The quenching factors related to self-regulated photoprotection or unavoidable photodamage are mediated by the $\mathrm{q}_{\mathrm{n}}$ mechanisms, which depress PECE both in the PSII antenna and in the RCII pool. The energydependent quenching $\left(\mathrm{q}_{\mathrm{e}}\right)$ operates in the pigment bed. It is triggered by the development of the light-driven trans-thylakoid proton gradient (Krause \& Jahns 2004), and is mediated by the xanthophyll cycling that dissipates excessive light energy as heat (Yamamoto \& Nakayama 1962, Demmig-Adams 1990). The state transition mechanisms, $\mathrm{q}_{\mathrm{t}}$ (Bonaventura \& Myers 1969) that balance the uneven excitation delivery between PSII and photosystem I (PSI) are also operative in the pigment bed. Generally they only affect the functional absorption cross-section $\sigma_{\text {PSII }}$ (Behrenfeld \& Kolber 1999), but the energy spillover from PSII to PSI also affects PECE (Allen 1992). These transition mechanisms are less important in high light conditions (Krause \& Weis 1991), i.e. in the upper layers of the water column, and thus have little impact on PECE

Table 1. Abbreviations

Euphotic depth (m)

Mixing depth (m)

Downward plane irradiance (PAR, 400 to $700 \mathrm{~nm}, \mu \mathrm{mol}$ quanta $\mathrm{m}^{-2} \mathrm{~s}^{-1}$ )

$E_{d}$ below the surface film

Spectral downward plane irradiance (PAR, $\mu$ mol quanta $\mathrm{m}^{-2} \mathrm{~s}^{-1} \mathrm{~nm}^{-1}$ )

Diffuse attenuation coefficient of downward plane irradiance $\left(\mathrm{m}^{-1}\right)$

Average diffuse attenuation coefficient of downward plane irradiance $\left(\mathrm{m}^{-1}\right)$

Absorption coefficient of particulate matter (400 to $700 \mathrm{~nm}, \mathrm{~m}^{-1} \mathrm{~nm}^{-1}$ )

Absorption coefficient of phytoplankton (400 to $700 \mathrm{~nm}, \mathrm{~m}^{-1} \mathrm{~nm}^{-1}$ )

Chl a-specific absorption of phytoplankton (400 to $700 \mathrm{~nm}, \mathrm{~m}^{2} \mathrm{mg} \mathrm{chl} a^{-1} \mathrm{~nm}^{-1}$ )

$\mathrm{Chl} a$-specific, wavelength-dependent absorption by phytoplankton (400 to $700 \mathrm{~nm}, \mathrm{~m}^{2} \mathrm{mg} \mathrm{chl}^{-1}$ )

Maximum light utilization coefficient [mg C $(\mathrm{mg} \mathrm{chl} \mathrm{a})^{-1} \mathrm{~h}^{-1}\left(\mu \mathrm{mol} \text { quanta } \mathrm{m}^{-2} \mathrm{~s}^{-1}\right)^{-1}$ ]

Light-saturated photosynthetic rate [mg C $\left(\mathrm{mg} \mathrm{chl} \mathrm{a}^{-1} \mathrm{~h}^{-1}\right]$

Light saturation parameter ( $\mu \mathrm{mol}$ quanta $\mathrm{m}^{-2} \mathrm{~s}^{-1}$ )

$\mathrm{E}_{\mathrm{d}}$ at $\mathrm{P}_{\max }\left(\mu \mathrm{mol}\right.$ quanta $\mathrm{m}^{-2} \mathrm{~s}^{-1}$ )

Light level at the onset of decrease in the vertical trend of $\mathrm{F}_{\mathrm{q}}{ }^{\prime} / \mathrm{F}_{\mathrm{m}}{ }^{\prime}\left(\mu \mathrm{mol}\right.$ quanta $\mathrm{m}^{-2} \mathrm{~s}^{-1}$ )

Light level at the onset of decrease in the vertical trend of $\mathrm{F}_{\mathrm{q}}{ }^{\prime} / \mathrm{F}_{\mathrm{v}}{ }^{\prime}$ ( $\mu \mathrm{mol}$ quanta $\mathrm{m}^{-2} \mathrm{~s}^{-1}$ )

Light level at the onset of decrease in the vertical trend of $\mathrm{F}_{\mathrm{v}}{ }^{\prime} / \mathrm{F}_{\mathrm{m}}{ }^{\prime}\left(\mu \mathrm{mol}\right.$ quanta $\left.\mathrm{m}^{-2} \mathrm{~s}^{-1}\right)$

Minimum dark-adapted fluorescence yield, $\mathrm{q}_{\mathrm{n}} \sim 0 / \mathrm{q}_{\mathrm{p}} \rightarrow 1$

Maximum dark-adapted fluorescence yield, $\mathrm{q}_{\mathrm{n}} \sim 0 / \mathrm{q}_{\mathrm{p}} \rightarrow 0$

Minimum fluorescence yield at the ambient irradiance, measured after a dark treatment of $\sim 1 \mathrm{~s}$, $0<\mathrm{q}_{\mathrm{n}}<1 / \mathrm{q}_{\mathrm{p}} \rightarrow 1$

Steady-state fluorescence yield at the ambient irradiance $0<\mathrm{q}_{\mathrm{n}}<1 / 0<\mathrm{q}_{\mathrm{p}}<1$

Maximum fluorescence yield at the ambient irradiance $0<q_{n}<1 / q_{p} \rightarrow 0$

Potential photochemical energy conversion efficiency in the dark-adapted state $\left(\mathrm{F}_{\mathrm{m}}-\mathrm{F}_{\mathrm{o}}\right) / \mathrm{F}_{\mathrm{m}}$

Effective photochemical energy conversion efficiency at the ambient irradiance $\left(\mathrm{F}_{\mathrm{m}}{ }^{\prime}-\mathrm{F}^{\prime}\right) / \mathrm{F}_{\mathrm{m}}{ }^{\prime}$

Maximum photochemical energy conversion efficiency at the ambient irradiance $\left(\mathrm{F}_{\mathrm{m}}{ }^{\prime}-\mathrm{F}_{\mathrm{o}}{ }^{\prime}\right) / \mathrm{F}_{\mathrm{m}}{ }^{\prime}$

PSII efficiency factor $\left(\mathrm{F}_{\mathrm{m}}{ }^{\prime}-\mathrm{F}^{\prime}\right) /\left(\mathrm{F}_{\mathrm{m}}{ }^{\prime}-\mathrm{F}_{\mathrm{o}}{ }^{\prime}\right)$

Depth of the onset of decrease in the vertical trend of $\mathrm{F}_{\mathrm{q}}{ }^{\prime} / \mathrm{F}_{\mathrm{m}}{ }^{\prime}(\mathrm{m})$

Depth of the onset of decrease in the vertical trend of $\mathrm{F}_{\mathrm{q}}{ }^{\prime} / \mathrm{F}_{\mathrm{v}}{ }^{\prime}(\mathrm{m})$

Depth of the onset of decrease in the vertical trend of $\mathrm{F}_{\mathrm{v}}{ }^{\prime} / \mathrm{F}_{\mathrm{m}}{ }^{\prime}(\mathrm{m})$

Impact of $\mathrm{q}_{\mathrm{n}}$ mechanisms of the decrease of $\mathrm{F}_{\mathrm{q}}{ }^{\prime} / \mathrm{F}_{\mathrm{m}}{ }^{\prime}$ above $\delta\left(\mathrm{F}_{\mathrm{q}}{ }^{\prime} / \mathrm{F}_{\mathrm{m}}{ }^{\prime}\right)$ (dimensionless, 0 to 1 )

Impact of $\mathrm{q}_{\mathrm{n}}$ mechanisms on the decrease of $\mathrm{F}_{\mathrm{q}}{ }^{\prime} / \mathrm{F}_{\mathrm{m}}{ }^{\prime}$ above $\delta\left(\mathrm{F}_{\mathrm{v}}{ }^{\prime} / \mathrm{F}_{\mathrm{m}}{ }^{\prime}\right)$, i.e. in the part of the water column where the $\mathrm{q}_{\mathrm{n}}$ mechanisms have an effect (dimensionless, 0 to 1 )

Functional absorption cross-section of PSII at the ambient irradiance $\left(\AA^{2} \mathrm{q}^{-1}\right)$ 
there. However, $\mathrm{q}_{\mathrm{t}}$ may have a pronounced impact on PECE measured at low light levels or even in darkness (Campbell et al. 1998).

Thermal dissipation in RCII may depress PECE by temporally inactivating an $\mathrm{RC}$ without the need for any de novo synthesis of D1 protein (Weis \& Berry 1987, Gorbunov et al. 2001). PSII heterogeneity transforms RCIIs as heat sinks that cannot run photochemistry (Lavergne \& Leci 1993, Strasser et al. 2004). Photoinhibition $\left(\mathrm{q}_{\mathrm{i}}\right)$ is defined as the reduced photosynthetic efficiency and/or capacity at supraoptimal ambient light (Hofstraat et al. 1994, Winters et al. 2003 and references therein). It is by nature an undesired condition in which the damage rate of the D1 protein exceeds the capacity of the de novo repair processes (Neale 1987), and the photoinactivated RCIIs begin to accumulate. It leads to slowly-recovering, if not irreversible, photodamage.

Thus far the $q_{n}$ effect has been quantified by the formulations $\left(F_{m}-F_{m}{ }^{\prime}\right) / F_{m}{ }^{\prime}$ (Bilger \& Björkman 1990), or $\left(F_{m}-F_{m}{ }^{\prime}\right) / F_{m}$ (Gorbunov et al. 2001). As far as we know, any attempt relying on the PECE forms $F_{q}{ }^{\prime} / F_{m}{ }^{\prime}$ and $\mathrm{F}_{\mathrm{v}}{ }^{\prime} / \mathrm{F}_{\mathrm{m}}{ }^{\prime}$ has not been reported. We tested this option in situ using fast repetition rate (FRR) fluorometry, a robust tool for probing the variable fluorescence transients. The FRR fluorometer probes the intact phytoplankton community at high frequency, and has 2 channels providing the varying effect of light. Considerable attention has been directed towards resolving the horizontal (Babin et al. 1996, Sosik \& Olson 2002, Hiscock et al. 2003, Moore et al. 2005), vertical (Boyd \& Abraham 2001, Vaillancourt et al. 2003, Suggett et al. 2006), long-term (Raateoja et al. 2004a) and diurnal (Behrenfeld \& Kolber 1999, Boyd \& Abraham 2001, Suzuki et al. 2002, Levy et al. 2004) variability in the FRR parameters. However, studies probing the small-scale FRR-based variability in order to clarify the photoacclimation of the natural phytoplankton are rather scarce (but see Moore et al. 2003, Moore et al. 2006).

We assessed the effects of $q_{n}$ and $q_{p}$ in the water column using the high-frequency data of $\mathrm{F}_{\mathrm{q}}{ }^{\prime} / \mathrm{F}_{\mathrm{m}}{ }^{\prime}$ and $\mathrm{F}_{\mathrm{v}}{ }^{\prime} / \mathrm{F}_{\mathrm{m}}{ }^{\prime}$. Furthermore, we modelled $\mathrm{F}_{\mathrm{q}}{ }^{\prime} / \mathrm{F}_{\mathrm{m}}{ }^{\prime}, \mathrm{F}_{\mathrm{v}}{ }^{\prime} / \mathrm{F}_{\mathrm{m}}$ and $\mathrm{F}_{\mathrm{q}}{ }^{\prime} / \mathrm{F}_{\mathrm{v}}{ }^{\prime}$ as a function of the ambient light, and supplemented the data with the ${ }^{14} \mathrm{C}$-based P-E (photosynthesis-irradiance) parameters in order to yield insight into the optimal light for PSII photochemistry and photosynthesis.

\section{THEORETICAL BACKGROUND}

The cornerstone of our approach was the constant flushing of the dark chamber of the FRR fluorometer during the deployments. According to contemporary terminology, the minimum $\left(\mathrm{F}_{\mathrm{o}}\right)$ and maximum $\left(\mathrm{F}_{\mathrm{m}}\right)$ dark-adapted fluorescence yields are described as $\mathrm{q}_{\mathrm{n}} \sim 0 / \mathrm{q}_{\mathrm{p}} \rightarrow 1$, and $\mathrm{q}_{\mathrm{n}} \sim 0 / \mathrm{q}_{\mathrm{p}} \rightarrow 0$, respectively (van Kooten \& Snel 1990, Kolber \& Falkowski 1993). Thus, a darkadaptation period of sufficient duration is needed in order to maximize $q_{p}$ and minimize $q_{n}$. The flushing rate of the dark chamber $\left(\sim 1 \mathrm{~s}^{-1}\right.$ in the present study, in practice extremely difficult to accurately determine) allows the oxidation of all components on the acceptor side of the PSII, this happening in milliseconds (Falkowski \& Raven 1997). Our assumption may be compromised only at the highest light levels near to the surface (Baker \& Oxborough 2003). Hardly any of the $\mathrm{q}_{\mathrm{n}}$ components have sufficient time to relax in this time frame; they have a $t_{1 / 2}$ of $\sim 1 \mathrm{~min}$ and beyond (Krause \& Weis 1991). This allowed us to differentiate the depressing effects of $\mathrm{q}_{\mathrm{p}}$ and $\mathrm{q}_{\mathrm{n}}$ on PECE. The dark channel PECE was the result of the $q_{n}$ effect on the potential PECE, while the light channel PECE was further subject to the $q_{p}$ effect (Moore et al. 2005).

Naturally, the flushing of the dark chamber of the FRR-fluorometer does not affect the interpretation of the light channel parameters, namely, the steady-state $\left(F^{\prime}, 0<q_{n}<1 / 0<q_{p}<1\right)$ and maximum fluorescence yields $\left(F_{m}{ }^{\prime}, 0<q_{n}<1 / q_{p} \rightarrow 0\right)$. However, both $F_{o}$ and $F_{m}$ are affected. We conclude that, firstly, $F_{o}$ is best described by $0<q_{n}<1 / q_{p} \rightarrow 1$, which clearly meets the definition of the minimum fluorescence yield at the ambient irradiance $\left(F_{0}^{\prime}\right)$ (van Kooten \& Snel 1990, Kolber \& Falkowski 1993). This conclusion allowed us to calculate $F_{\mathrm{q}}{ }^{\prime} / \mathrm{F}_{\mathrm{v}}{ }^{\prime}$. The highest observed $\mathrm{F}_{\mathrm{q}}{ }^{\prime} / \mathrm{F}_{\mathrm{v}}{ }^{\prime}$ values were close to unity (0.996 to 0.998$)$, thus corroborating the validity of our approach. Secondly, $F_{m}$ is best described by $0<q_{n}<1 / q_{p} \rightarrow 0$, which matches the definition of $F_{m}$ '. However, it is not clearly known how the second-scale dark phase (allowing the $\mathrm{Q}_{\mathrm{A}}$ pool and probably some components downstream of that to oxidize) and the immediate single turnover (ST) saturation protocol (reducing the $\mathrm{Q}_{\mathrm{A}}$ pool) shaped the overall redox state of the acceptor side of PSII. The PECE from the dark channel was interpreted as $\mathrm{F}_{\mathrm{v}}{ }^{\prime} / \mathrm{F}_{\mathrm{m}}{ }^{\prime}$, but keeping in mind that the maximum yield may not be equivalent to the true $F_{m}{ }^{\prime}$.

\section{MATERIALS AND METHODS}

Study area. Stations were categorized into 5 main groups (Fig. 1) according to geographic and hydrographic criteria. The resulting division can also be considered to represent various levels of autochthonous (phytoplankton) and allochthonous, i.e. terrestrial (humic substances, suspended matter), influence on the optical properties of the water. All of these provinces are categorized as the Case 1 water bodies 
by Morel \& Prieur (1977), and the shelf seas belong to oceanic type III according to the Jerlov (1976) classification.

Oceanic regions: The North Pacific Gyre (NPG) consisted of Stns N1 to N7, situated in the convergence belt of the NPG. Stns N1 to N3 at 160 to $180^{\circ} \mathrm{W}$ were only moderately mixed, and are together denoted as $\mathrm{NPG}_{\mathrm{W}}$. Stns N4 to N7 at 150 to $180^{\circ} \mathrm{E}$, within the effect of the Kuroshio extension, were deeply mixed, and are together denoted as $\mathrm{NPG}_{\mathrm{E}}$. Both these regions had surface temperatures of 15 to $18^{\circ} \mathrm{C}$ and salinities of 34.4 to 34.8 .

Waters of the Kuroshio current (KUR) consisted of Stns K1 to K4, situated off the southwest coast of Japan. The stations were hydrodynamically highly variable, as they were situated in the area where the Oyashio current and KUR collide, forming complex eddy fields. This region had surface temperatures of 18 to $22^{\circ} \mathrm{C}$ and salinities of 34.6 to 34.7 .

Shelf seas: The East China Sea (ECS) consisted of Stns E1 to E9, on the continental shelf in the southern ECS. These stations were in the frontal area between the warm Kuroshio waters and the colder waters of the Yellow Sea and the Chinese coastal shelf. This region had surface temperatures between 13 and $17^{\circ} \mathrm{C}$ and salinities ranging from 33.7 to 34.6 .

The Sea of Japan (SOJ) consisted of Stns S1 to S6, in the Yamato and Ulleung basins in the SOJ. These stations are situated in the subpolar front area between the Kuroshio branch (Thushima current) and the cold, deeply mixed water masses of the Japan basin. This region had surface temperatures of 10 to $12^{\circ} \mathrm{C}$ and salinities ranging from 34.0 to 34.4 .

Sampling. Sampling and water column measurements were carried out on-board the NOAA vessel RV 'Ronald H. Brown' from 15 March to 20 April 2001, as part of the Asian Pacific Regional Aerosol Characterization Experiment (ACE-Asia). In order to minimize the impacts of any diurnal effects on the phytoplankton fluorescence data, only those stations that were visited between 09:00 and 12:00 h local time were taken into consideration.

Hydrography: Water column hydrography (temperature and conductivity) was probed with a Sea-Bird SBE 911 Plus system (Sea-Bird Electronics). The water for the analytical measurements was sampled with CTD's 12 l Niskin rosette bottles. The surface mixed layer (SML) was defined as the layer above
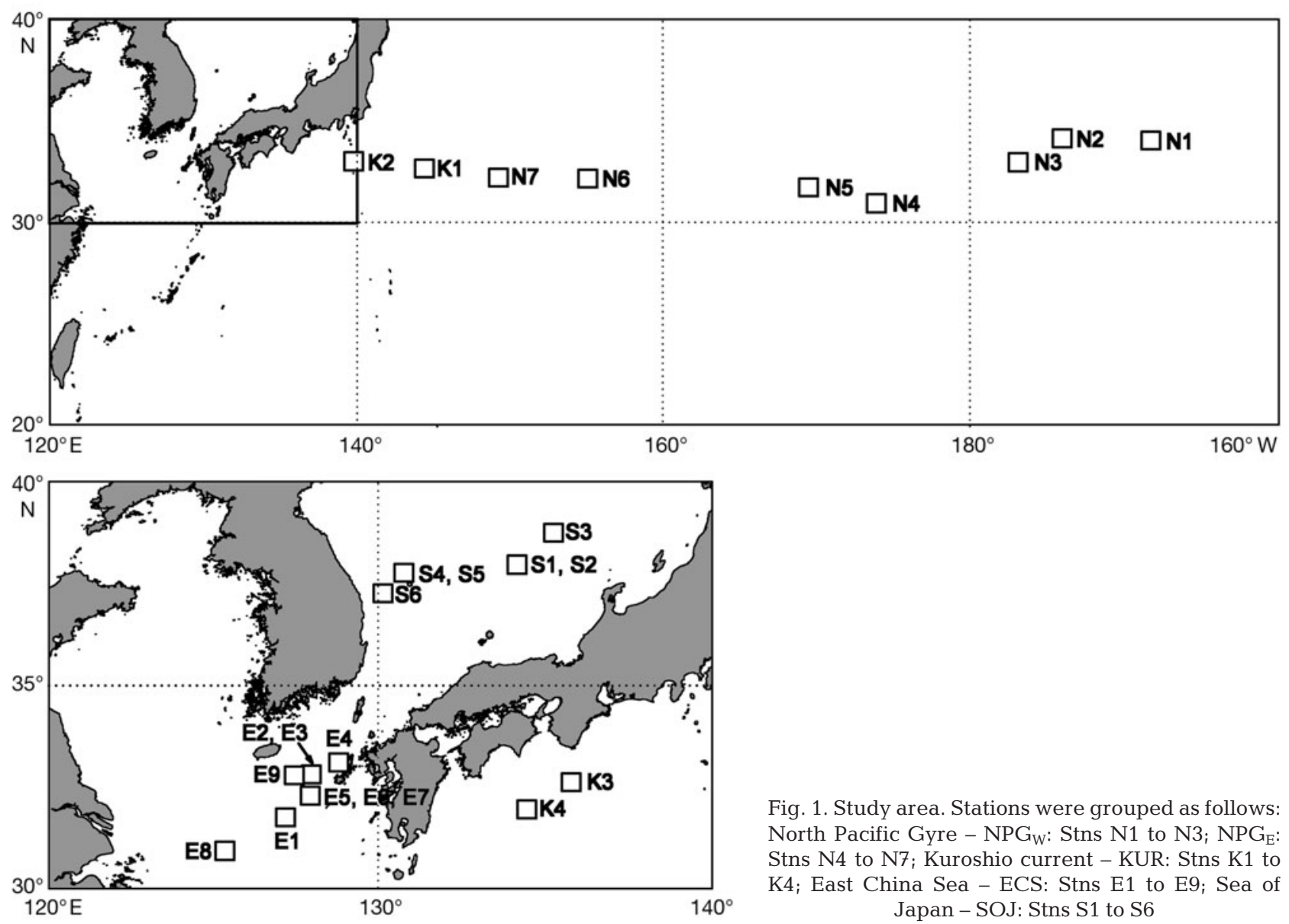

Fig. 1. Study area. Stations were grouped as follows: North Pacific Gyre - NPG ${ }_{W}$ : Stns N1 to N3; NPG : Stns N4 to N7; Kuroshio current - KUR: Stns K1 to K4; East China Sea - ECS: Stns E1 to E9; Sea of Japan - SOJ: Stns S1 to S6 
the shallowest depth at which a density anomaly $\geq 0.01 \mathrm{~kg} \mathrm{~m}^{-3} \mathrm{~m}^{-1}$ took place. This depth is the mixing depth $\left(\mathrm{z}_{\mathrm{SML}}\right)$.

Radiometric measurements: Downward plane irradiance, $E_{d}$, and spectral downward plane irradiance, $\mathrm{E}_{\mathrm{d}}(\lambda)$, were measured with a multispectral free-fall profiling reflectance radiometer PRR-800 (Biospherical Instruments). The average diffuse attenuation coefficient of downward plane irradiance $\left(\mathrm{K}_{\mathrm{av}}\right)$ was determined by weighting the diffuse attenuation coefficient of downward plane irradiance $\left(\mathrm{K}_{\mathrm{d}}\right)$ according to Kirk (2003):

$$
\mathrm{K}_{\mathrm{av}}=\left(\int_{0}^{z_{\mathrm{eu}}} \mathrm{K}_{\mathrm{d}}(z) \times \mathrm{E}_{\mathrm{d}}(z)\right) \times\left(\int_{0}^{z_{\mathrm{eu}}} \mathrm{E}_{\mathrm{d}}(z)\right)^{-1}
$$

where $z_{\text {eu }}(\mathrm{m})$ refers to the euphotic depth. A tentative estimate for $z_{\text {eu }}$ was determined as the depth corresponding to $1 \%$ of the light below the surface, $\mathrm{E}_{\mathrm{d}}\left(0_{-}\right)$. The final $z_{\text {eu }}$ was defined as $4.6 \times \mathrm{K}_{\mathrm{av}}{ }^{-1}$, and the optical depth as $\mathrm{K}_{\mathrm{av}} \times z$.

Spectroscopic measurements: The absorption coefficient of particulate matter, $a_{p}(\lambda)$, was determined by a quantitative filter technique (Mitchell 1990). The optical density (OD, 300 to $800 \mathrm{~nm}$ ) of total particulate matter collected onto GF/F filters (Whatman) was measured using a Cary 100 UV-Vis spectrophotometer (Varian). After determination, filters were extracted with $100 \%$ methanol (Kishino et al. 1985), and the OD of the extracted filters was measured to estimate detrital absorption, $\mathrm{a}_{\mathrm{d}}(\lambda)$. The raw ODs were set to zero at $800 \mathrm{~nm}$. The absorption coefficient of phytoplankton, $a_{p h}(\lambda)$, is given by $a_{p}(\lambda)-a_{d}(\lambda)$. The chlorophyll a-specific (chl a) absorption coefficient of phytoplankton, $\mathrm{a}_{\mathrm{ph}} *(\lambda)$, was determined by dividing $\mathrm{a}_{\text {ph }}(\lambda)$ by the chl a level, while the chl a-specific, wavelength-dependent absorption of phytoplankton $\left(\overline{\mathrm{a}}_{\mathrm{ph}} *\right.$ ) was calculated by weighting the $\mathrm{a}_{\mathrm{ph}} *(\lambda)$ by $\mathrm{E}_{\mathrm{d}}(\lambda)$ over the photosynthetically active radiation (PAR) region.

The maximum light utilization coefficient $(\alpha)$ and the functional absorption cross-section of PSII at the ambient irradiance $\left(\sigma_{\text {PSII }}{ }^{\prime}\right)$ were scaled to the in situ light field according to Suggett et al. (2001). The scaling factors covered only sampling depths providing $a_{p h} *(\lambda)$, and were modelled against depth for both the oceanic regions and the shelf seas by a nonlinear regression analysis to cover all the FRR measuring depths.

Analytical measurements: Nutrients: Nutrient samples were filtered through GF/F filters, and the filtrates were stored frozen at $-20^{\circ} \mathrm{C}$ until analyzed for dissolved nitrate and phosphate with a TrAAcs 2000 continuous flow analytical system (Bran-Luebbe).

Pigments: Samples for pigment analysis were collected onto GF/F filters, and were stored in liquid $\mathrm{N}$ until the HPLC analysis. The ODS-2 C18 column
HPLC separation technique was employed (Wright et al. 1991).

P-E response: The photosynthetic response to a light gradient was evaluated in 20 steps up to $1400 \mu \mathrm{mol}$ quanta $\mathrm{m}^{-2} \mathrm{~s}^{-1}$ with ${ }^{14} \mathrm{C}-\mathrm{CO}_{2}$ uptake (Steemann Nielsen 1952). The spectral light flux inside the custom-built incubators is shown in Fig. 2. The activity of the ${ }^{14} \mathrm{C}$-labelled $\mathrm{NaHCO}_{3}$ aqueous solution was $56 \mathrm{MBq} \mathrm{m}^{-1}$, and $370 \mathrm{kBq}$ was added to $1 \mathrm{ml}$ samples. Radioactivity of the samples was measured with an LS1701 liquid scintillation counter (Beckman Coulter). For the analogy with the variable fluorescence measurements, $\alpha$ and the light-saturated photosynthetic rate $\left(\mathrm{P}_{\max }\right)$ were determined according to a model ignoring photoinhibition (Webb et al. 1974). The light saturation parameter $\mathrm{E}_{\mathrm{k}}$ was calculated as $\mathrm{P}_{\max } / \alpha . \mathrm{E}_{\mathrm{k}}$ data were combined into 2 groups: (1) $E_{k}$ (surface), samples in the upper $10 \mathrm{~m}_{\text {; }}$ and (2) $\mathrm{E}_{\mathrm{k}}$ (deep), samples beneath $10 \mathrm{~m}$. We estimated the light level where $\mathrm{P}_{\max }$ was first met along the course of the exponential P-E curve, equalling the onset of light saturation of photosynthesis; this level was denoted as $\mathrm{E}\left(\mathrm{P}_{\max }\right)$. A production estimate equalling $0.99 \times \mathrm{P}_{\max }$ in the $\mathrm{P}-\mathrm{E}$ equation provided a proxy for $\mathrm{E}\left(\mathrm{P}_{\max }\right)$. We also formed 2 groups for $\mathrm{E}\left(\mathrm{P}_{\max }\right), \mathrm{E}\left(\mathrm{P}_{\max }\right.$ surface $)$ and $\mathrm{E}\left(\mathrm{P}_{\max }\right.$ deep $)$, in analogy to the $\mathrm{E}_{\mathrm{k}}$ data.

Variable fluorescence measurements: The fluorescence induction was probed with a FAST ${ }^{\text {tracka }}$ I FRRfluorometer (Chelsea Technologies Group) (Fig. 2). The calibration and measurement protocol was according to Raateoja et al. (2004b). Individual FRRacquisitions were the averages of 10 successive flash sequences.

The battery-powered FRR-fluorometer together with the external PAR and pressure sensors were deployed using a stern-mounted A-frame. The data from the upward casts were used. The FRR-data from the upper $5 \mathrm{~m}$ were excluded, and thus the red-light effect (sensu Raateoja et al. 2004a) may only have had leverage in the one or 2 uppermost observations. The depth interval between successive measurements of the same channel was $\sim 1.5 \mathrm{~m}$. The FRR-fluorometer was used in the autoacquire-mode with a default photomultiplier gain of 16 . The gains were in the auto-ranging mode, with 30 and 70 as the lower and the upper threshold values, respectively.

Raw fluorescence signal was not corrected for background fluorescence. The fluorescence yields and $\sigma_{\mathrm{PSII}}{ }^{\prime}$ were derived from the raw fluorescence data using Matlab-based v5 software, based on the generallyacknowledged model (Kolber et al. 1998), developed by S. Laney (unpubl.). The full unconstrained iterative model, involving minimum and maximum fluorescence yields, $\sigma_{\text {PSII }}$ and connectivity between RCIIs, was used in the retrieval process. 

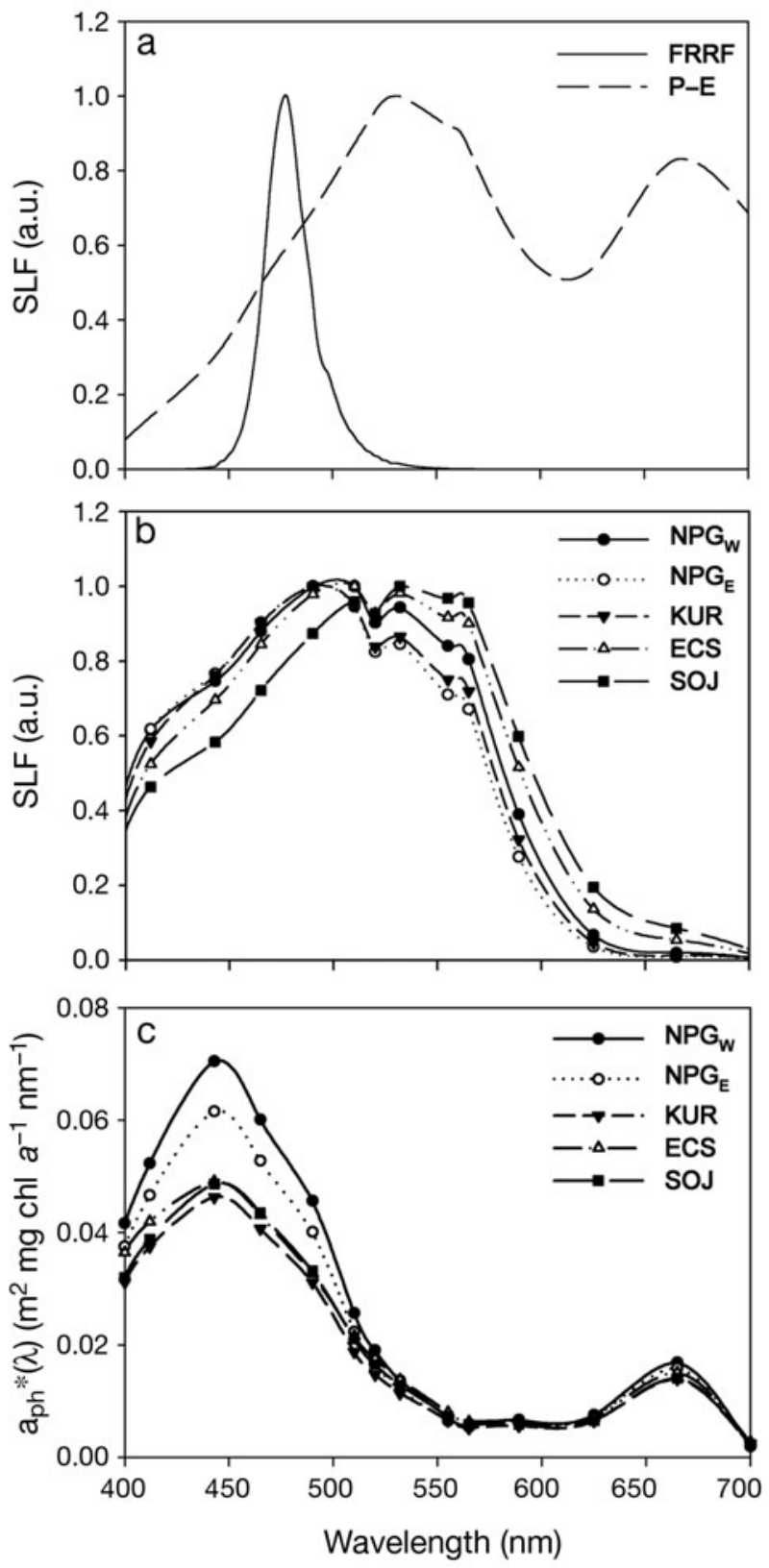

Fig. 2. (a) Spectral light flux (SLF, arbitrary units [a.u.]) of the fast repetition rate fluorometer (FRRF) and the P-E incubator as quanta. (b) Typical light field at 1 optical depth. Spectra in (a) and (b) are scaled to unity. (c) Chl a-specific absorption coefficient of phytoplankton, $\mathrm{a}_{\mathrm{ph}} *(\lambda)$ as the upper $40 \mathrm{~m}$ average. $\mathrm{NPG}_{\mathrm{WE}}$ : North Pacific Gyre (west/east); KUR: Kuroshio current; ECS: East China Sea; SOJ: Sea of Japan

FRR-based parameters as a function of depth: The vertical data of $\mathrm{F}_{\mathrm{v}}{ }^{\prime} / \mathrm{F}_{\mathrm{m}}{ }^{\prime}, \mathrm{F}_{\mathrm{q}}{ }^{\prime} / \mathrm{F}_{\mathrm{m}}{ }^{\prime}$ and $\mathrm{F}_{\mathrm{q}}{ }^{\prime} / \mathrm{F}_{\mathrm{v}}{ }^{\prime}$ were smoothed with a Loess-method, a locally-weighted regression analysis (Cleveland 1979), using an R statistical environment. A span level of 0.5 was used, and the output was binned at $0.1 \mathrm{~m}$ intervals.
Our study setup could not differentiate between the effects of the various $q_{n}$ mechanisms (e.g. $q_{e}, q_{i}$ ) on PECE, but we probed a combined effect of all the $q_{n}$ mechanisms, and referred it as $q_{n}$. Any decrease in $\mathrm{F}_{\mathrm{q}}{ }^{\prime} / \mathrm{F}_{\mathrm{m}}{ }^{\prime}$ was a result of the combined effect of $\mathrm{q}_{\mathrm{p}}$ and $\mathrm{q}_{\mathrm{n}}$, while any decrease in $F_{v}{ }^{\prime} / F_{m}{ }^{\prime}$ was a sole result of the $\mathrm{q}_{\mathrm{n}}$ effect. This distinction allowed us to differentiate the effects of $q_{p}$ and $q_{n}$ on the PECE decrease; all decreases of PECE that were not caused by $\mathrm{q}_{\mathrm{n}}$, were assumed to be caused by $\mathrm{q}_{\mathrm{p}}$.

The first sign of $q_{p}$ vertically was designated as occurring at a depth of $\delta\left(F_{\mathrm{q}}{ }^{\prime} / \mathrm{F}_{\mathrm{m}}{ }^{\prime}\right)$ (Fig. 3). This depth represents the onset of the decrease in $F_{\mathrm{q}}{ }^{\prime} / \mathrm{F}_{\mathrm{m}}{ }^{\prime}$, and thus a deviation of the vertical $F_{\mathrm{q}}{ }^{\prime} / \mathrm{F}_{\mathrm{m}}{ }^{\prime}$ and $\mathrm{F}_{\mathrm{v}}{ }^{\prime} / \mathrm{F}_{\mathrm{m}}{ }^{\prime}$ trends, and was defined as the depth at which the upper $95 \% \mathrm{CI}$ of $\mathrm{F}_{\mathrm{q}}{ }^{\prime} / \mathrm{F}_{\mathrm{m}}{ }^{\prime}$ equalled the lower $95 \% \mathrm{CI}$ of $\mathrm{F}_{\mathrm{v}}{ }^{\prime} / \mathrm{F}_{\mathrm{m}}{ }^{\prime}$. The emergence of $\mathrm{q}_{\mathrm{n}}$ vertically was designated as occurring at a depth of $\delta\left(\mathrm{F}_{\mathrm{v}}{ }^{\prime} / \mathrm{F}_{\mathrm{m}}{ }^{\prime}\right)$ (Fig. 3). This depth represents the onset of the decrease in $\mathrm{F}_{\mathrm{v}}{ }^{\prime} / \mathrm{F}_{\mathrm{m}}{ }^{\prime}$, and was defined as the depth at which the upper $95 \% \mathrm{CI}$ of $\mathrm{F}_{\mathrm{v}}{ }^{\prime} / \mathrm{F}_{\mathrm{m}}{ }^{\prime}$ equalled $\mathrm{F}_{\mathrm{v}}{ }^{\prime} / \mathrm{F}_{\mathrm{m}}{ }^{\prime}$ at its maximum above $\delta\left(\mathrm{F}_{\mathrm{q}}{ }^{\prime} / \mathrm{F}_{\mathrm{m}}{ }^{\prime}\right)$.

The $q_{n}$ effect on the PECE decrease $\left(q_{n} / q_{t o t}\right)$ at depth $\mathrm{z}$ was defined as:

$$
\begin{aligned}
& \left(\mathrm{q}_{\mathrm{n}} / \mathrm{q}_{\mathrm{tot}}\right)_{\mathrm{z}}=\left[\mathrm{q}_{\mathrm{n}} /\left(\mathrm{q}_{\mathrm{n}}+\mathrm{q}_{\mathrm{p}}\right)\right]_{\mathrm{z}}= \\
& \frac{\left(\mathrm{F}_{\mathrm{v}}^{\prime} / \mathrm{F}_{\mathrm{m}}{ }^{\prime}\right)_{\delta\left(\mathrm{F}_{\mathrm{q}}{ }^{\prime} / \mathrm{F}_{\mathrm{m}}{ }^{\prime}\right)}-\left(\mathrm{F}_{\mathrm{v}}{ }^{\prime} / \mathrm{F}_{\mathrm{m}}{ }^{\prime}\right)_{\mathrm{z}}}{\left(\mathrm{F}_{\mathrm{q}}{ }^{\prime} / \mathrm{F}_{\mathrm{m}}{ }^{\prime}\right)_{\delta\left(\mathrm{F}_{\mathrm{q}} / \mathrm{F}_{\mathrm{m}}{ }^{\prime}\right)}-\left(\mathrm{F}_{\mathrm{q}}{ }^{\prime} / \mathrm{F}_{\mathrm{m}}\right)_{\mathrm{z}}}
\end{aligned}
$$

The vertically averaged $\mathrm{q}_{\mathrm{n}} / \mathrm{q}_{\text {tot }}$ was estimated from the uppermost FRR-measurements to $\delta\left(\mathrm{F}_{\mathrm{q}}{ }^{\prime} / \mathrm{F}_{\mathrm{m}}{ }^{\prime}\right)$. The resulting parameter $\left(\mathrm{q}_{\mathrm{n}} / \mathrm{q}_{\text {tot }}\right)_{\mathrm{q}}$ (the subscripted $\mathrm{q}$ denotes $F_{q}{ }^{\prime}$ ) describes to what extent $q_{n}$ depressed PECE in the part of the water column where PECE was decreased in general (Fig. 3):

$$
\begin{array}{r}
\left(\mathrm{q}_{\mathrm{n}} / \mathrm{q}_{\mathrm{tot}}\right)_{\mathrm{q}}=\left(\sum_{\mathrm{i}=\text { uppermost depth }}^{\delta\left(\mathrm{F}_{\mathrm{q}} / \mathrm{F}_{\mathrm{m}}{ }^{\prime}\right)}\left[\left(\mathrm{q}_{\mathrm{n}} / \mathrm{q}_{\text {tot }}\right)_{\mathrm{z}}\right]_{\mathrm{i}}\right) \times \\
\left(\delta\left(\mathrm{F}_{\mathrm{q}}{ }^{\prime} / \mathrm{F}_{\mathrm{m}}{ }^{\prime}\right)-\text { uppermost depth }\right)^{-1}
\end{array}
$$

The depth at which the $\mathrm{q}_{\mathrm{n}}$ effect overrode the $\mathrm{q}_{\mathrm{p}}$ effect was defined as $\left(\mathrm{q}_{\mathrm{n}} / \mathrm{q}_{\text {tot }}\right)_{\mathrm{q}}$ equalling 0.5 .

To obtain information about to what extent $\mathrm{q}_{\mathrm{n}}$ depressed PECE in the part of the water column where $\mathrm{q}_{\mathrm{n}}$ played a pronounced role, we had to convert $\mathrm{q}_{\mathrm{n}} / \mathrm{q}_{\text {tot }}$ to a special form $\left(\mathrm{q}_{\mathrm{n}} / \mathrm{q}_{\mathrm{tot}}\right)_{\mathrm{z}} *$ :

$$
\left(\mathrm{q}_{\mathrm{n}} / \mathrm{q}_{\mathrm{tot}}\right)_{\mathrm{z}} *=\frac{\left(\mathrm{F}_{\mathrm{v}}{ }^{\prime} / \mathrm{F}_{\mathrm{m}}{ }^{\prime}\right)_{\delta\left(\mathrm{F}_{\mathrm{v}}{ }^{\prime} / \mathrm{F}_{\mathrm{m}}{ }^{\prime}\right)}-\left(\mathrm{F}_{\mathrm{v}}{ }^{\prime} / \mathrm{F}_{\mathrm{m}}{ }^{\prime}\right)_{\mathrm{z}}}{\left(\mathrm{F}_{\mathrm{q}}{ }^{\prime} / \mathrm{F}_{\mathrm{m}}{ }^{\prime}\right)_{\delta\left(\mathrm{F}_{\mathrm{v}}{ }^{\prime} / \mathrm{F}_{\mathrm{m}}{ }^{\prime}\right)}-\left(\mathrm{F}_{\mathrm{q}}{ }^{\prime} / \mathrm{F}_{\mathrm{m}}\right)_{\mathrm{z}}}
$$

Now $\mathrm{q}_{\mathrm{n}} / \mathrm{q}_{\text {tot }}$ was calculated from the uppermost FRRmeasurements to $\delta\left(\mathrm{F}_{\mathrm{v}}{ }^{\prime} / \mathrm{F}_{\mathrm{m}}{ }^{\prime}\right)$. This definition of $\mathrm{q}_{\mathrm{n}} / \mathrm{q}_{\text {tot }}$ serves only Eq. (5), and will not be dealt with any further in this article, except in Fig. 3. The parameter $\left(\mathrm{q}_{\mathrm{n}} / \mathrm{q}_{\mathrm{tot}}\right)_{\mathrm{v}}$, where the subscript $\mathrm{v}$ denotes $\mathrm{F}_{\mathrm{v}}{ }^{\prime}$, was calculated as: 

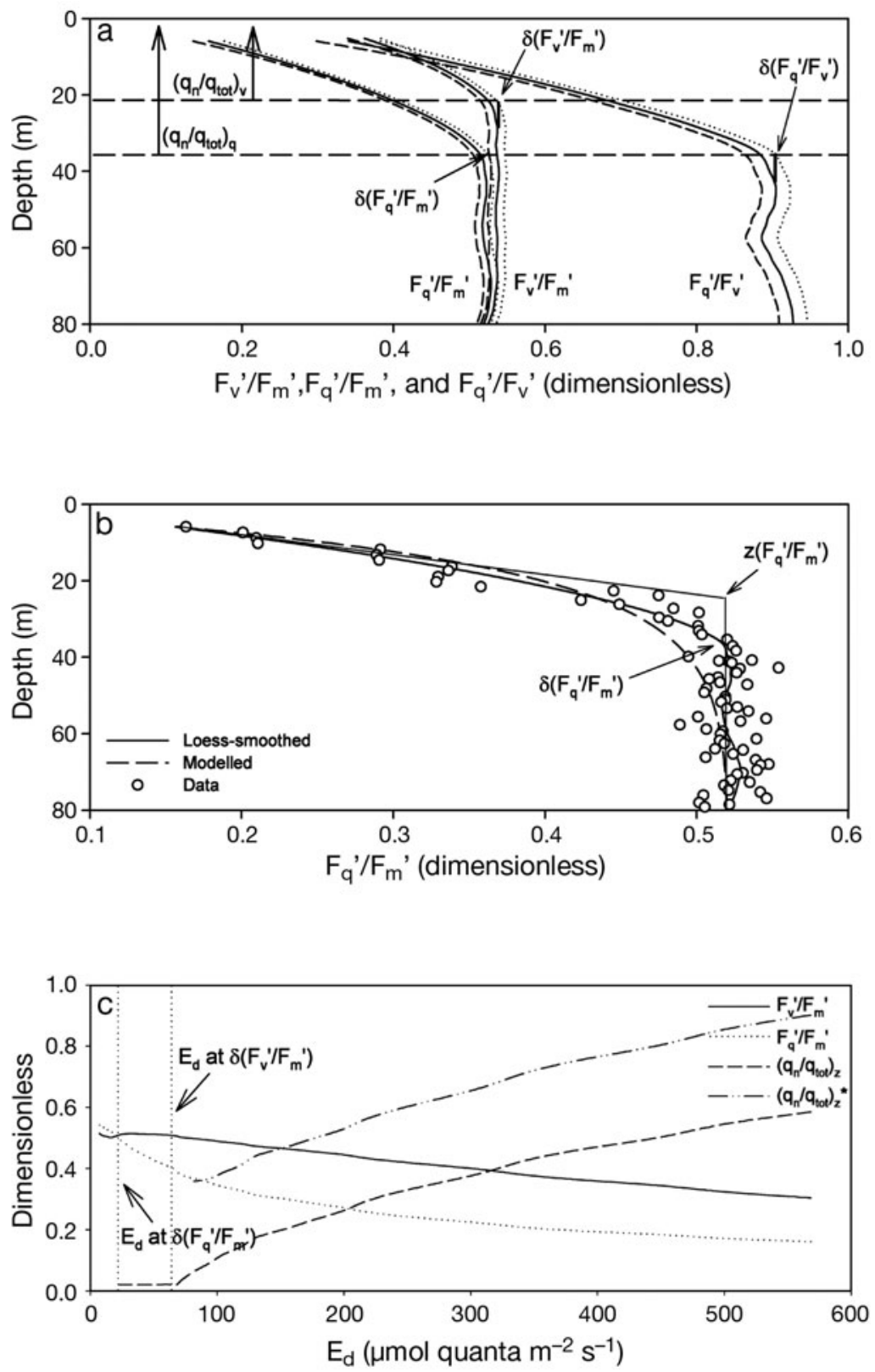

Fig. 3. (a) Determination of $\delta\left(\mathrm{F}_{\mathrm{q}}{ }^{\prime} / \mathrm{F}_{\mathrm{m}}{ }^{\prime}\right), \delta\left(\mathrm{F}_{\mathrm{v}}{ }^{\prime} / \mathrm{F}_{\mathrm{m}}{ }^{\prime}\right)$, and $\delta\left(\mathrm{F}_{\mathrm{q}}{ }^{\prime} / \mathrm{F}_{\mathrm{v}}{ }^{\prime}\right) ;$ (solid line) Resulting fit; (dashed line) lower $95 \% \mathrm{CI}_{\text {; }}$ (dotted line) upper $95 \% \mathrm{CI}$ of the Loess-smoothing. Note that even though $\delta\left(\mathrm{F}_{\mathrm{q}}{ }^{\prime} / \mathrm{F}_{\mathrm{m}}{ }^{\prime}\right)$ and $\delta\left(\mathrm{F}_{\mathrm{q}}{ }^{\prime} / \mathrm{F}_{\mathrm{v}}{ }^{\prime}\right)$ should co-occur, they were not presumed to be the same, but the relationship was checked each time. Shown also are the parts of the water column on which the determination of $\left(\mathrm{q}_{\mathrm{n}} / \mathrm{q}_{\text {tot }}\right)_{\mathrm{q}}$ and $\left(\mathrm{q}_{\mathrm{n}} / \mathrm{q}_{\mathrm{tot}}\right)_{\mathrm{v}}$ are based. To clarify, the depths indicated by the horizontal dashed lines do not indicate $\left(\mathrm{q}_{\mathrm{n}} / \mathrm{q}_{\mathrm{tot}}\right)_{\mathrm{q}}$ and $\left(\mathrm{q}_{\mathrm{n}} / \mathrm{q}_{\mathrm{tot}}\right)_{\mathrm{v} i}$ these parameters are averaged vertically. (b) Difference between the Loess-based, $\delta\left(\mathrm{F}_{\mathrm{q}}{ }^{\prime} / \mathrm{F}_{\mathrm{m}}{ }^{\prime}\right)$, and the $\mathrm{P}-\mathrm{E}$ style approach, $\mathrm{z}\left(\mathrm{F}_{\mathrm{q}}{ }^{\prime} / \mathrm{F}_{\mathrm{m}}{ }^{\prime}\right)$. Data from Stn E4 are used as an example in (a) and (b). (c) Determination of the effects of $\mathrm{q}_{\mathrm{p}}$ and $\mathrm{q}_{\mathrm{n}}$. $\mathrm{q}_{\mathrm{p}}$ affects PECE from the $\mathrm{E}_{\mathrm{d}}$ at $\delta\left(\mathrm{F}_{\mathrm{q}}{ }^{\prime} / \mathrm{F}_{\mathrm{m}}{ }^{\prime}\right)$ upwards; in fact, below the $\mathrm{E}_{\mathrm{d}}$ at $\delta\left(\mathrm{F}_{\mathrm{v}}{ }^{\prime} / \mathrm{F}_{\mathrm{m}}{ }^{\prime}\right)$ it is the only depressing factor. At this light interval, $\left(\mathrm{q}_{\mathrm{n}} / \mathrm{q}_{\mathrm{tot}}\right)_{\mathrm{z}}$ is zero. From the light level of $\delta\left(\mathrm{F}_{\mathrm{v}}{ }^{\prime} / \mathrm{F}_{\mathrm{m}}{ }^{\prime}\right)$ upwards, $\mathrm{q}_{\mathrm{n}}$ is increasingly responsible for the PECE decrease, and $\left(\mathrm{q}_{\mathrm{n}} / \mathrm{q}_{\mathrm{tot}}\right)_{\mathrm{z}} *$ describes the true $\mathrm{q}_{\mathrm{n}}$ effect. $\left(\mathrm{q}_{\mathrm{n}} / \mathrm{q}_{\text {tot }}\right)_{\mathrm{q}}$ and $\left(\mathrm{q}_{\mathrm{n}} / \mathrm{q}_{\text {tot }}\right)_{\mathrm{v}}$ are both averaged values; $\left(\mathrm{q}_{\mathrm{n}} / \mathrm{q}_{\text {tot }}\right)_{\mathrm{q}}<$ $\left(\mathrm{q}_{\mathrm{n}} / \mathrm{q}_{\mathrm{tot}}\right)_{\mathrm{v}}$ because $\left(\mathrm{q}_{\mathrm{n}} / \mathrm{q}_{\text {tot }}\right)_{\mathrm{q}}$ includes the depth interval $\delta\left(\mathrm{F}_{\mathrm{q}}{ }^{\prime} / \mathrm{F}_{\mathrm{m}}{ }^{\prime}\right)$ to $\delta\left(\mathrm{F}_{\mathrm{v}}{ }^{\prime} / \mathrm{F}_{\mathrm{m}}{ }^{\prime}\right)$ where $\mathrm{q}_{\mathrm{n}}$ is zero. Stn $\mathrm{S} 2$ is used as an example. All parameters defined in Table 1 $\left(\mathrm{q}_{\mathrm{n}} / \mathrm{q}_{\mathrm{tot}}\right)_{\mathrm{v}}=\left(\sum_{\mathrm{i}=\text { uppermost depth }}^{\delta\left(\mathrm{F}_{\mathrm{v}}{ }^{\prime} / \mathrm{F}_{\mathrm{m}}{ }^{\prime}\right)}\left[\left(\mathrm{q}_{\mathrm{n}} / \mathrm{q}_{\text {tot }}\right)_{\mathrm{z}} *\right]_{\mathrm{i}}\right) \times$

$\left[\delta\left(\mathrm{F}_{\mathrm{v}}{ }^{\prime} / \mathrm{F}_{\mathrm{m}}{ }^{\prime}\right)-\text { uppermost depth }\right]^{-1}$

FRR-based parameters as a function of light: The light levels at which the trends of $\mathrm{F}_{\mathrm{v}}{ }^{\prime} / \mathrm{F}_{\mathrm{m}}{ }^{\prime}, \mathrm{F}_{\mathrm{q}}{ }^{\prime} / \mathrm{F}_{\mathrm{m}}{ }^{\prime}$ and $\mathrm{F}_{\mathrm{q}}{ }^{\prime} / \mathrm{F}_{\mathrm{v}}{ }^{\prime}$ started to decrease were calculated in analogy to the P-E results (Fig. 3). For clarity, these calculations were based on raw data, not the smoothed data. The determination of $\mathrm{E}\left(\mathrm{F}_{\mathrm{v}}{ }^{\prime} / \mathrm{F}_{\mathrm{m}}{ }^{\prime}\right), \mathrm{E}\left(\mathrm{F}_{\mathrm{q}}{ }^{\prime} / \mathrm{F}_{\mathrm{m}}{ }^{\prime}\right)$ and $\mathrm{E}\left(\mathrm{F}_{\mathrm{q}}{ }^{\prime} / \mathrm{F}_{\mathrm{v}}{ }^{\prime}\right)$ was based on the modified formulation of Webb et al. (1974):

$$
X_{i}=X_{\max } \times\left(A-e^{\left(\frac{-B x z}{X_{\max }}\right)}\right)
$$

where $X$ refers either to $F_{v}{ }^{\prime} / F_{m}{ }^{\prime}, F_{q}{ }^{\prime} / F_{m}{ }^{\prime}$ or $\mathrm{F}_{\mathrm{q}}{ }^{\prime} / \mathrm{F}_{\mathrm{v}}{ }^{\prime} ; \mathrm{A}$ and $\mathrm{B}$ are constants in the fitting process; and $\mathrm{z}$ is depth. We did not assume that $F_{\mathrm{v}}{ }^{\prime} / \mathrm{F}_{\mathrm{m}}{ }^{\prime}, \mathrm{F}_{\mathrm{q}}{ }^{\prime} / \mathrm{F}_{\mathrm{m}}{ }^{\prime}$ or $\mathrm{F}_{\mathrm{q}}{ }^{\prime} / \mathrm{F}_{\mathrm{v}}{ }^{\prime}$ would ever approach the zero-level in situ in the water column, thus, the constant A was allowed to vary from unity. B represents the diminution rate of $F_{\mathrm{v}}{ }^{\prime} / \mathrm{F}_{\mathrm{m}}{ }^{\prime}, \mathrm{F}_{\mathrm{q}}{ }^{\prime} / \mathrm{F}_{\mathrm{m}}{ }^{\prime}$ or $\mathrm{F}_{\mathrm{q}}{ }^{\prime} / \mathrm{F}_{\mathrm{v}}{ }^{\prime}$ towards the surface, and $\mathrm{X}_{\max }$ the maximum attainable level of $\mathrm{F}_{\mathrm{v}}{ }^{\prime} / \mathrm{F}_{\mathrm{m}}{ }^{\prime}, \mathrm{F}_{\mathrm{q}}{ }^{\prime} / \mathrm{F}_{\mathrm{m}}{ }^{\prime}$, or $\mathrm{F}_{\mathrm{q}}{ }^{\prime} / \mathrm{F}_{\mathrm{v}}{ }^{\prime}$. The threshold depth $\mathrm{z}(\mathrm{X})$ was calculated as: $\mathrm{z}(\mathrm{X})$ $=\mathrm{X}_{\mathrm{max}} / \mathrm{B}$. The vertical light data were used to convert $\mathrm{z}(\mathrm{X})$ to $\mathrm{E}(\mathrm{X})$, the latter being functionally analogous to $\mathrm{E}_{\mathrm{k}}$.

\section{RESULTS}

\section{General physicochemical setup of the regions}

The regions could be divided roughly into 2 groups with regard to $\mathrm{z}_{\mathrm{SML}}$ (Table 2). The stations in $\mathrm{NPG}_{\mathrm{E}}$ and SOJ had a deep SML, while $\mathrm{NPG}_{\mathrm{W}}$ and particularly ECS had a shallow SML. In KUR, the complex eddy fields were reflected in the huge variation in $\mathrm{z}_{\text {SML }}(<20 \mathrm{~m}$ to $>90 \mathrm{~m})$. The vertical nutrient trends reflected well the hydrographical differences between the oceanic regions and the shelf seas (Fig. 4). In the oceanic regions, nutrient levels increased rather steadily and moderately, if at all, in the upper $100 \mathrm{~m}$, and no clear nutricline could be observed. The nutrient levels did not show any relation to $\mathrm{z}_{\mathrm{SML}}$ in the hydrodynamically-active KUR (data not shown). In the shelf seas, the nutrient gradients were steeper than in the 
Table 2. Oceanic regions studied. Parameters as means \pm SD. See Table 1 for units and definitions; superscript $=$ number of observations. Parameters having a vertical dimension: means from the surface to a depth of $40 \mathrm{~m}$, except the FRR-based parameters- $\sigma_{\mathrm{PSII}}{ }^{\prime}, \mathrm{F}_{\mathrm{q}}{ }^{\prime} / \mathrm{F}_{\mathrm{m}}{ }^{\prime}$, $\mathrm{F}_{\mathrm{v}}{ }^{\prime} / \mathrm{F}_{\mathrm{m}}{ }^{\prime}$ and $\mathrm{F}_{\mathrm{q}}{ }^{\prime} / \mathrm{F}_{\mathrm{v}}{ }^{\prime}$ - which are given as means of the $10 \mathrm{~m}$ layer below $\delta\left(\mathrm{F}_{\mathrm{q}}{ }^{\prime} / \mathrm{F}_{\mathrm{m}}{ }^{\prime}\right)$. + : parameter was not normally distributed (Lilliefors' test: $\mathrm{p}<0.05)$, and non-parametric Kruskall-Wallis ANOVA and Mann-Whitney $U$-test were used. Otherwise parametric ANOVA and Tukey's test were used. p-values: ${ }^{*}<0.05,{ }^{* *}<0.01,{ }^{* * *}<0.001$. Post hoc groups: regions having the same superscript number belong statistically $(p<0.05)$ to the same group. $\mathrm{N}_{\mathrm{W}}=\mathrm{NPG}_{\mathrm{W}}, \mathrm{N}_{\mathrm{E}}=\mathrm{NPG}_{\mathrm{E}}, \mathrm{K}=\mathrm{KUR}, \mathrm{E}=\mathrm{ECS}, \mathrm{S}=\mathrm{SOJ}$, nd = no data, ns = non-significant

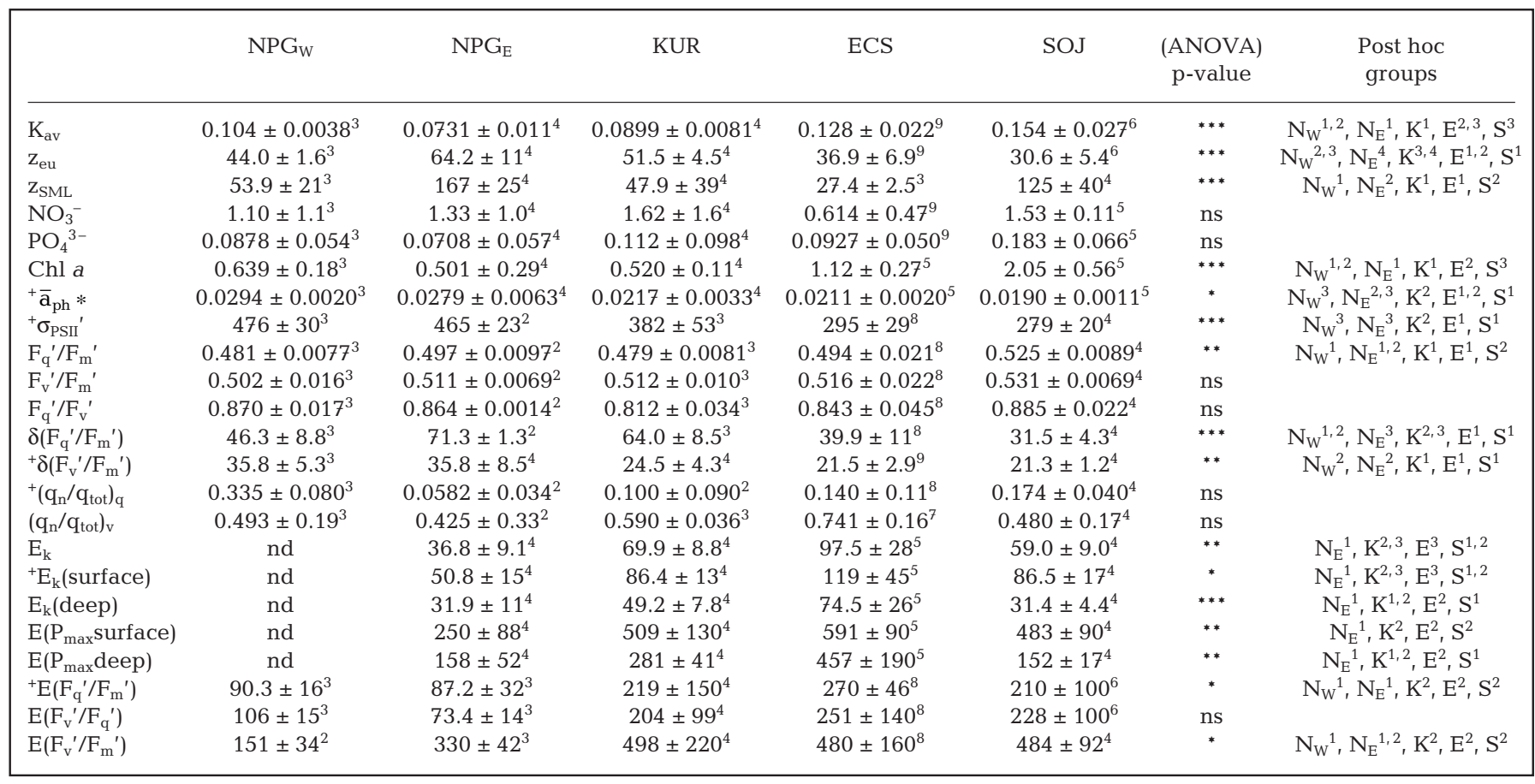

ocean, and the nutricline was situated at 30 to $50 \mathrm{~m}$. For ECS, this was below $\mathrm{z}_{\mathrm{SML}}$. The vertical patterns of $\mathrm{NO}_{3}{ }^{-}$and $\mathrm{PO}_{4}{ }^{3-}$ were highly correlated (Pearson's $\mathrm{r}>$ 0.91, Bonferroni $\mathrm{p}<0.001, \mathrm{n}>23$ in all regions).

$\mathrm{K}_{\mathrm{av}}$ presented a clearly increasing gradient from the oceanic regions to the shelf seas (Table 2). The general $\mathrm{K}_{\mathrm{av}}$ level in $\mathrm{NPG}_{\mathrm{W}}$ and KUR was 0.09 to $0.10 \mathrm{~m}^{-1}$, and $N P Q_{E}$ had even clearer water, with $K_{a v}$ typically $\sim 0.07 \mathrm{~m}^{-1}$. ECS water attenuated light more efficiently, with $\mathrm{K}_{\mathrm{av}}$ typically 0.11 to $0.13 \mathrm{~m}^{-1}$, but values such as 0.09 (Stn E7) and $0.16 \mathrm{~m}^{-1}$ (Stn E8) were observed due to variable water physics (e.g. various water masses, Kuroshio influence, shallowness giving chances for resuspension). The SOJ waters attenuated light most efficiently; $\mathrm{K}_{\mathrm{av}}$ ranged from 0.12 to $0.19 \mathrm{~m}^{-1}$, with the highest values in the Ulleung basin (Stns S4 to S6). Stations under the Kuroshio influence in $\mathrm{NPG}_{\mathrm{E}}$ and KUR were most biased towards the blue end of the PAR region, with a maximum light transmission below $500 \mathrm{~nm}$ (Fig. 2). Stations in ECS and especially in SOJ, under heavier terrestrial influence, had a broad maximum light transmission from 500 to $570 \mathrm{~nm}$. NPG waters were spectrally in between these 2 extremes; they had a maximum transmission below $500 \mathrm{~nm}$, but a clearly higher transmission from 500 to $550 \mathrm{~nm}$ that was observed in $\mathrm{NPG}_{\mathrm{E}}$ and KUR.
The regions could be divided roughly into 2 groups with regard to the ratio of $z_{e u}$ to $z_{S M L}$. In $N P G_{E}$ and SOJ, this ratio was clearly below unity (0.1 to 0.6$)$. The $\mathrm{NPG}_{\mathrm{W}}$ stations were also mainly below unity, with one station (Stn N1) above it. In these regions, phytoplankton were circulating to below the euphotic zone, if the mixing rates were high enough to force this. In ECS, this ratio was above unity (1.1 to 1.3), suggesting that phytoplankton stayed within the euphotic zone. In the hydrographically variable KUR, the ratio was either clearly below $(0.6$ to 0.7$)$ or clearly above unity (3.5 to 3.7 ).

\section{Photoacclimative state of phytoplankton}

Based on the ratios of group-specific diagnostic pigments, phytoplankton in the oceanic regions were dominated by picocyanophytes (Prochlorococcus spp., Prochlorococcaceae and Synechococcus spp., Cyanophyceae), with relatively low numbers of eukaryotic nanoplankton. In the shelf seas, the pico-sized compartment was less occupied, whereas dinoflagellates (Dinophyceae) and diatoms (Bacillariophyceae) dominated the phytoplankton assemblage. Dinoflagellates dominated in ESC, and diatoms in the colder SOJ 

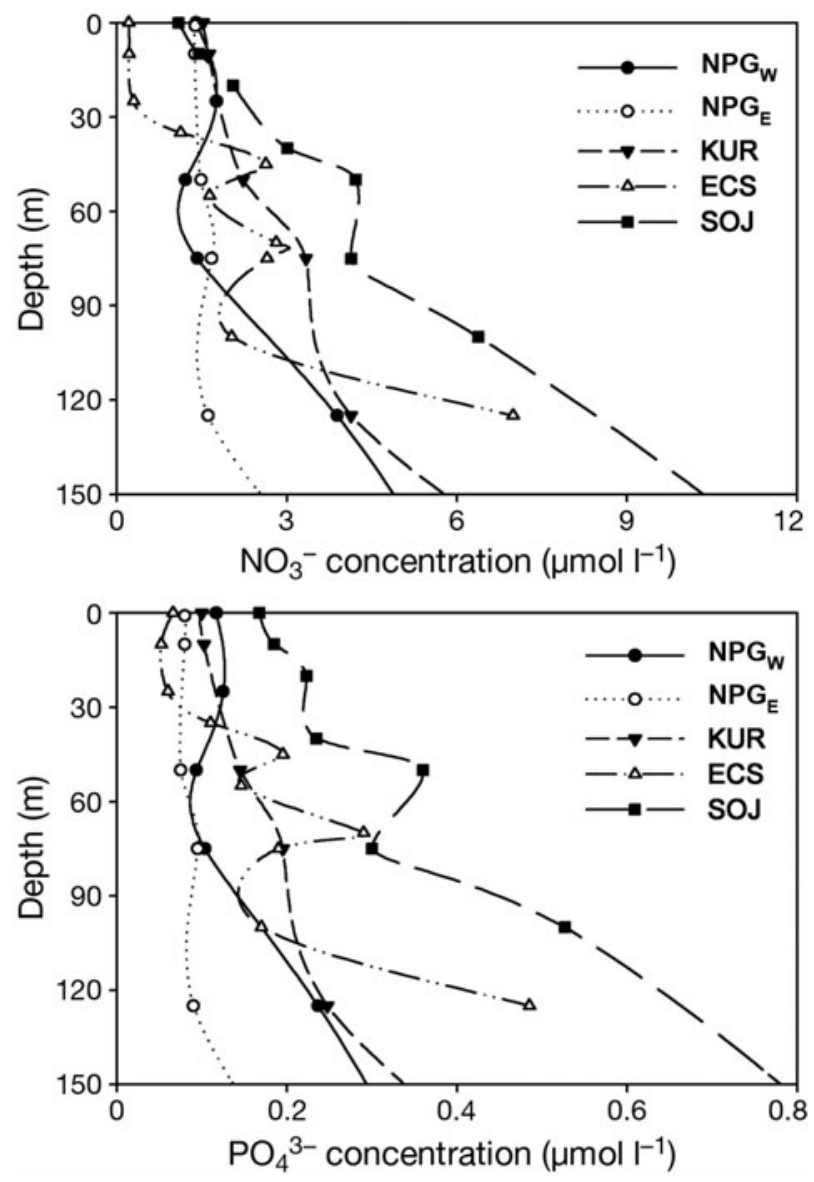

Fig. 4. Average $\mathrm{NO}_{3}{ }^{-}$and $\mathrm{PO}_{4}{ }^{3-}$ patterns. Abbreviations as in Fig. 2

waters. The chl a level in the oceanic regions was generally $<1 \mu \mathrm{g} \mathrm{l}^{-1}$, whereas in the shelf seas it was usually $>1 \mu \mathrm{g}^{-1}$ (Table 2). The highest levels (1.8 to $3.3 \mu \mathrm{g} \mathrm{l}^{-1}$ ) were observed at Stns S4 to S6. The variability in chl a levels explained two-thirds of the variability in $\mathrm{K}_{\mathrm{av}}$ (linear regression for $K_{\mathrm{av}}$ and the average chl a from 10 to $50 \mathrm{~m}, F=43$, df =1,19, $\left.\mathrm{r}^{2}=0.68, \mathrm{p}=<0.001\right)$. Chl $a$ levels decreased markedly from $100 \mathrm{~m}$ downwards in the oceanic regions. In the shelf seas, the decreases from $40 \mathrm{~m}$ (ECS) and $25 \mathrm{~m}$ (SOJ) downwards were in agreement with the changes in the physical $\left(\mathrm{z}_{\mathrm{eu}}, \mathrm{z}_{\mathrm{SML}}\right)$ and chemical (nutricline) environments. The exception was $z_{S M L}$ in SOJ, as the stations at SOJ were deeply mixed. This suggests that our method of assessing $z_{S M L}$ did not properly describe the circulation pattern of phytoplankton in SOJ.

Phytoplankton in $\mathrm{NPG}_{\mathrm{W}}$ and $\mathrm{NPG}_{\mathrm{E}}$ showed significantly higher light-absorption potential than in the other regions $\left(\overline{\mathrm{a}}_{\mathrm{ph}} *\right.$, Table 2$)$, and a higher blue-to-red absorption ratio $\left(\mathrm{a}_{\mathrm{ph}} *[443]\right.$ to $\mathrm{a}_{\mathrm{ph}} *[665]$, Fig. 2$)$, indicating a stronger input of auxiliary pigments and/or a lower pigment packaging effect. The higher $\sigma_{\mathrm{PSII}}$ ' level in $\mathrm{NPG}_{\mathrm{W}}$ and $\mathrm{NPG}_{\mathrm{E}}$ than in the other regions sug- gested that, if auxiliary pigments played a role here, these pigments were at least partly photosynthetic in nature (Table 2). On the other hand, small-sized phytoplankon and the low chl a level in $\mathrm{NPG}_{\mathrm{W}}$ and $\mathrm{NPG}_{\mathrm{E}}$ were probably reflected in the level of pigment packaging; these regions presented somewhat higher $\mathrm{a}_{\mathrm{ph}} *(665)$ than did the other regions (Fig. 2). $\overline{\mathrm{a}}_{\mathrm{ph}} *$ increased towards deeper layers in the oceanic regions (Pearson's $\mathrm{r}=0.71,0.48$ and 0.43; Bonferroni $\mathrm{p}<0.05$, 0.11 and $0.14 ; \mathrm{n}=9,12$ and 13 for $\mathrm{NPG}_{\mathrm{W}}, \mathrm{NPG}_{\mathrm{E}}$ and KUR, respectively), but not in ECS and SOJ, although there too the $\overline{\mathrm{a}}_{\mathrm{ph}} *$ values at $\geq 50 \mathrm{~m}$ deviated from those closer to the surface (data not shown). $E_{k}$ decreased with depth (no data from $\mathrm{NPG}_{\mathrm{W}}$, Pearson's $\mathrm{r}=-0.76$, $-0.84,-0.44$, and -0.72 ; Bonferroni $\mathrm{p}<0.01$, $<0.001$, 0.08 , and $<0.01 ; \mathrm{n}=12,12,17$, and 15 for $\mathrm{NPG}_{\mathrm{E}}, \mathrm{KUR}$, ECS and SOJ, respectively). This vertical trend in $\mathrm{E}_{\mathrm{k}}$ was very distinctive at every station visited. Phytoplankton in $\mathrm{NPG}_{\mathrm{E}}$ had a lower $\mathrm{E}_{\mathrm{k}}$ level as compared to the other regions (Table 2).

\section{Variable fluorescence characteristics}

Vertical trends of the PECE forms

$\delta\left(F_{\mathrm{q}}{ }^{\prime} / \mathrm{F}_{\mathrm{m}}{ }^{\prime}\right)$ varied from 39 to $74 \mathrm{~m}$ in the oceanic regions and from 19 to $50 \mathrm{~m}$ in the shelf seas. It got closer to the surface in the optical gradient from $\mathrm{NPG}_{\mathrm{E}}$ to SOJ (Table 2). $\delta\left(\mathrm{F}_{\mathrm{v}}{ }^{\prime} / \mathrm{F}_{\mathrm{m}}{ }^{\prime}\right)$ was situated at considerably shallower depths than $\delta\left(\mathrm{F}_{\mathrm{q}}{ }^{\prime} / \mathrm{F}_{\mathrm{m}}{ }^{\prime}\right)$ - from 21 to $44 \mathrm{~m}$ in the oceanic regions, and from 17 to $26 \mathrm{~m}$ in the shelf seas - but presented a similar interregional pattern. $\mathrm{K}_{\mathrm{av}}$ was inversely related to the stationwise variation in $\delta\left(\mathrm{F}_{\mathrm{q}}{ }^{\prime} / \mathrm{F}_{\mathrm{m}}{ }^{\prime}\right)$ and $\delta\left(\mathrm{F}_{\mathrm{v}}{ }^{\prime} / \mathrm{F}_{\mathrm{m}}{ }^{\prime}\right)$ (Table 3$)$. A higher $\mathrm{K}_{\mathrm{av}}$ led the light to propagate less efficiently within the water column, and both $\mathrm{q}_{\mathrm{p}}$ and $\mathrm{q}_{\mathrm{n}}$ started functioning at shallower depths.

\section{Impact of the $\mathrm{q}_{\mathrm{n}}$ mechanisms}

Of the 19 stations where $\mathrm{q}_{\mathrm{n}} / \mathrm{q}_{\text {tot }}$ could be determined, $\mathrm{q}_{\mathrm{n}}$ was able to override $\mathrm{q}_{\mathrm{p}}$ as the predominant quencher of PECE at 11 stations. In reality, $\mathrm{q}_{\mathrm{n}} / \mathrm{q}_{\text {tot }}$ was probably higher than now illustrated, but methodological deficiencies (e.g. the interference of the red photons) forced us to reject the FRR-data from the upper 5 to $7 \mathrm{~m}$, depending on the station. $\mathrm{q}_{\mathrm{n}} / \mathrm{q}_{\text {tot }}$ would have been strongest in the very near vicinity of the surface. $\mathrm{q}_{\mathrm{n}}$ overrode $\mathrm{q}_{\mathrm{p}}$ at depths of 8 to $12 \mathrm{~m}$ in KUR, ECS and SOJ (data not shown). Stations at $\mathrm{NPG}_{\mathrm{W}}$ and $\mathrm{NPG}_{\mathrm{E}}$ were distinct with corresponding depths of 13 to $24 \mathrm{~m}$. With regard to the light levels corresponding to these depths, $\mathrm{NPG}_{\mathrm{W}}$ was again distinct with an average 
Table 3. Stepwise forward linear regression analysis for parameters $\delta\left(F_{\mathrm{q}}{ }^{\prime} / \mathrm{F}_{\mathrm{m}}{ }^{\prime}\right), \delta\left(\mathrm{F}_{\mathrm{v}}{ }^{\prime} / \mathrm{F}_{\mathrm{m}}{ }^{\prime}\right), \quad\left(\mathrm{q}_{\mathrm{n}} / \mathrm{q}_{\mathrm{tot}}\right)_{\mathrm{q}}, \quad\left(\mathrm{q}_{\mathrm{n}} / \mathrm{q}_{\mathrm{tot}}\right)_{\mathrm{v}}, \mathrm{E}_{\mathrm{k}}(\mathrm{surface})$, $\mathrm{E}_{\mathrm{k}}(\mathrm{deep}), \mathrm{E}\left(\mathrm{P}_{\max }\right.$ surface $), \mathrm{E}\left(\mathrm{P}_{\max } \mathrm{deep}\right), \mathrm{E}\left(\mathrm{F}_{\mathrm{q}}{ }^{\prime} / \mathrm{F}_{\mathrm{m}}{ }^{\prime}\right), \mathrm{E}\left(\mathrm{F}_{\mathrm{q}}{ }^{\prime} / \mathrm{F}_{\mathrm{v}}{ }^{\prime}\right)$ and $\mathrm{E}\left(\mathrm{F}_{\mathrm{v}}{ }^{\prime} / \mathrm{F}_{\mathrm{m}}{ }^{\prime}\right)$. Value of an independent parameter indicates the percentage of variation the parameter explains $;$ related. $\mathrm{p}$-to-enter $=0.15$

\begin{tabular}{|c|c|c|c|c|c|c|c|c|c|c|}
\hline \multirow[t]{2}{*}{ Dependent } & \multicolumn{6}{|c|}{ - Independent } & \multirow[t]{2}{*}{$F$} & \multirow[t]{2}{*}{ df } & \multirow{2}{*}{$\mathrm{p}$} & \multirow[t]{2}{*}{$\mathrm{r}^{2}$} \\
\hline & $\mathrm{K}_{\mathrm{av}}$ & $\mathrm{z}_{\mathrm{SML}}$ & $\mathrm{z}_{\mathrm{eu}} \times \mathrm{z}_{\mathrm{SML}}{ }^{-1}$ & $\mathrm{E}_{\mathrm{d}}(0-)$ & $\mathrm{E}_{\mathrm{d}}$ at $\delta\left(\mathrm{F}_{\mathrm{q}}{ }^{\prime} / \mathrm{F}_{\mathrm{m}}{ }^{\prime}\right)$ & $\mathrm{E}_{\mathrm{d}}$ at $\delta\left(\mathrm{F}_{\mathrm{v}}{ }^{\prime} / \mathrm{F}_{\mathrm{m}}{ }^{\prime}\right)$ & & & & \\
\hline$\delta\left(\mathrm{F}_{\mathrm{q}}{ }^{\prime} / \mathrm{F}_{\mathrm{m}}{ }^{\prime}\right)$ & $77(-)$ & $2(+)$ & + & - & $20(-)$ & - & 137 & 3,8 & $<0.001$ & 0.97 \\
\hline$\delta\left(\mathrm{F}_{\mathrm{v}}{ }^{\prime} / \mathrm{F}_{\mathrm{m}}{ }^{\prime}\right)$ & $30(-)$ & + & + & - & - & $47(-)$ & 34 & 2,16 & $<0.001$ & 0.79 \\
\hline$\left(\mathrm{q}_{\mathrm{n}} / \mathrm{q}_{\mathrm{tot}}\right)_{\mathrm{q}}$ & + & $17(-)$ & + & - & $32(+)$ & $35(-)$ & 17 & 3,10 & $<0.001$ & 0.78 \\
\hline$\left(\mathrm{q}_{\mathrm{n}} / \mathrm{q}_{\mathrm{tot}}\right)_{\mathrm{v}}$ & + & $31(-)$ & + & + & - & + & 5.8 & 1,13 & $<0.05$ & 0.25 \\
\hline $\mathrm{E}_{\mathrm{k}}$ (surface) & $21(+)$ & $32(-)$ & + & + & - & - & 6.2 & 2,11 & $<0.05$ & 0.45 \\
\hline$E_{k}($ deep $)$ & + & + & $40(+)$ & $26(+)$ & - & - & 9.8 & 2,10 & $<0.01$ & 0.60 \\
\hline $\mathrm{E}\left(\mathrm{P}_{\max } \mathrm{surface}\right)$ & $16(+)$ & $41(-)$ & + & + & - & - & 7.7 & 2,12 & $<0.01$ & 0.49 \\
\hline $\mathrm{E}\left(\mathrm{P}_{\max } \mathrm{deep}\right)$ & $7(-)$ & + & $74(+)$ & + & - & - & 17 & 2,8 & $<0.01$ & 0.76 \\
\hline $\mathrm{E}\left(\mathrm{F}_{\mathrm{q}}{ }^{\prime} / \mathrm{F}_{\mathrm{v}}{ }^{\prime}\right)$ & + & + & + & $29(+)$ & - & - & 6.5 & 1,22 & $<0.05$ & 0.19 \\
\hline $\mathrm{E}\left(\mathrm{F}_{\mathrm{q}}^{\prime} / \mathrm{F}_{\mathrm{m}}^{\prime}\right)$ & + & + & + & $43(+)$ & - & - & 16 & 1,22 & $<0.001$ & 0.39 \\
\hline $\mathrm{E}\left(\mathrm{F}_{\mathrm{v}}{ }^{\prime} / \mathrm{F}_{\mathrm{m}}{ }^{\prime}\right)$ & + & + & + & $34(+)$ & - & - & 11 & 1,17 & $<0.01$ & 0.37 \\
\hline
\end{tabular}

value of $140 \mu \mathrm{mol}$ quanta $\mathrm{m}^{-2} \mathrm{~s}^{-1}$, while the other regions had an average of 360 , with only one station $<200 \mu \mathrm{mol}$ quanta $\mathrm{m}^{-2} \mathrm{~s}^{-1}$.

$\left(\mathrm{q}_{\mathrm{n}} / \mathrm{q}_{\mathrm{tot}}\right)_{\mathrm{q}}$ varied from 0.02 to 0.48 between stations with an average of 0.18 (Table 2). Regionally, $\mathrm{NPG}_{\mathrm{W}}$ presented a clearly higher level than the other regions. $\left(\mathrm{q}_{\mathrm{n}} / \mathrm{q}_{\mathrm{tot}}\right)_{\mathrm{q}}$ was largely governed by the vertical distance between $\delta\left(\mathrm{F}_{\mathrm{q}}{ }^{\prime} / \mathrm{F}_{\mathrm{m}}{ }^{\prime}\right)$ and $\delta\left(\mathrm{F}_{\mathrm{v}}{ }^{\prime} / \mathrm{F}_{\mathrm{m}}{ }^{\prime}\right)$, which was reflected in the duality of a direct relation between the $\mathrm{E}_{\mathrm{d}}$ at $\delta\left(\mathrm{F}_{\mathrm{q}}{ }^{\prime} / \mathrm{F}_{\mathrm{m}}{ }^{\prime}\right)$ and $\left(\mathrm{q}_{\mathrm{n}} / \mathrm{q}_{\mathrm{tot}}\right)_{\mathrm{q}}$, and an inverse relation between the $\mathrm{E}_{\mathrm{d}}$ at $\delta\left(\mathrm{F}_{\mathrm{v}}{ }^{\prime} / \mathrm{F}_{\mathrm{m}}{ }^{\prime}\right)$ and $\left(\mathrm{q}_{\mathrm{n}} / \mathrm{q}_{\mathrm{tot}}\right)_{\mathrm{q}}$ (Table 3).

$\left(\mathrm{q}_{\mathrm{n}} / \mathrm{q}_{\mathrm{tot}}\right)_{\mathrm{v}}$ varied from 0.19 to 0.97 between stations with an average of 0.59 (Table 2). Thus, the average level of $\left(\mathrm{q}_{\mathrm{n}} / \mathrm{q}_{\mathrm{tot}}\right)_{\mathrm{v}}$ was clearly higher than that of $\left(\mathrm{q}_{\mathrm{n}} / \mathrm{q}_{\mathrm{tot}}\right)_{\mathrm{q}}$. Regionally, no statistical differences were found between the levels, but the level in ECS was still clearly higher than that of the other regions. $\mathrm{z}_{\mathrm{SML}}$ was inversely related to $\left(\mathrm{q}_{\mathrm{n}} / \mathrm{q}_{\mathrm{tot}}\right)_{\mathrm{v}}$ and to a lesser extent to $\left(\mathrm{q}_{\mathrm{n}} / \mathrm{q}_{\text {tot }}\right)_{\mathrm{q}}$ (Table 3). Phytoplankton experienced a higher average light environment in a shallower SML, and were forced to respond promptly with the induction of photoprotective $\mathrm{q}_{\mathrm{n}}$ mechanisms.

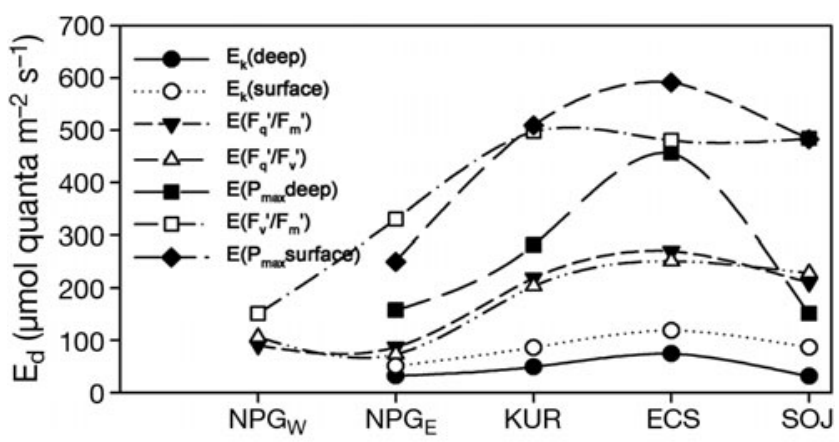

Fig. 5. Interregional variability in the irradiance response parameters. ${ }^{14} \mathrm{C}$-based data were not available for $\mathrm{NPG}_{\mathrm{W}}$

\section{FRR- and ${ }^{14} \mathrm{C}$-based light response parameters}

The ${ }^{14} \mathrm{C}$-based parameters $\mathrm{E}_{\mathrm{k}}$ (deep) and $\mathrm{E}_{\mathrm{k}}$ (surface) were the first light-response parameters met with along an increasing light gradient (Table 2, Fig. 5). $\mathrm{E}\left(\mathrm{P}_{\max }\right.$ deep) and $\mathrm{E}\left(\mathrm{P}_{\max }\right.$ surface $)$ were, on average, $\sim 5$-fold higher as compared to the corresponding $\mathrm{E}_{\mathrm{k}}$ levels. $\mathrm{E}\left(\mathrm{F}_{\mathrm{q}}{ }^{\prime} / \mathrm{F}_{\mathrm{v}}{ }^{\prime}\right)$ and $\mathrm{E}\left(\mathrm{F}_{\mathrm{q}}{ }^{\prime} / \mathrm{F}_{\mathrm{m}}{ }^{\prime}\right)$ were the first observed FRR-based parameters, and $\mathrm{E}\left(\mathrm{F}_{\mathrm{v}}{ }^{\prime} / \mathrm{F}_{\mathrm{m}}{ }^{\prime}\right)$ was, on average, $\sim$-fold higher as compared to either $\mathrm{E}\left(\mathrm{F}_{\mathrm{q}}{ }^{\prime} / \mathrm{F}_{\mathrm{m}}{ }^{\prime}\right)$ or $\mathrm{E}\left(\mathrm{F}_{\mathrm{q}}{ }^{\prime} / \mathrm{F}_{\mathrm{v}}{ }^{\prime}\right)$. Light levels across the entire study were categorized in ratios of 1:2:4:4:6:9:10 for $\mathrm{E}_{\mathrm{k}}(\mathrm{deep}): \mathrm{E}_{\mathrm{k}}$ (surface): $\mathrm{E}\left(\mathrm{F}_{\mathrm{q}}{ }^{\prime} / \mathrm{F}_{\mathrm{m}}{ }^{\prime}\right): \mathrm{E}\left(\mathrm{F}_{\mathrm{q}}{ }^{\prime} / \mathrm{F}_{\mathrm{v}}{ }^{\prime}\right): \mathrm{E}\left(\mathrm{P}_{\max } \operatorname{deep}\right): \mathrm{E}\left(\mathrm{F}_{\mathrm{v}}{ }^{\prime} / \mathrm{F}_{\mathrm{m}}{ }^{\prime}\right): \mathrm{E}\left(\mathrm{P}_{\max }\right.$ surface). Most of these differences were statistically significant [ANOVA, log-transformed data: $\mathrm{F}_{6,130}=44$, $\mathrm{p}<0.001$, Tukey's test: $\mathrm{p}<0.05$ in all comparisons, except between $\mathrm{E}\left(\mathrm{F}_{\mathrm{v}}{ }^{\prime} / \mathrm{F}_{\mathrm{m}}{ }^{\prime}\right)$ and $\mathrm{E}\left(\mathrm{P}_{\max }\right.$ surface $)$, and between $\mathrm{E}\left(\mathrm{F}_{\mathrm{q}}{ }^{\prime} / \mathrm{F}_{\mathrm{v}}{ }^{\prime}\right), \mathrm{E}\left(\mathrm{F}_{\mathrm{q}}{ }^{\prime} / \mathrm{F}_{\mathrm{m}}{ }^{\prime}\right)$ and $\left.\mathrm{E}\left(\mathrm{P}_{\max } \mathrm{deep}\right)\right]$. Phytoplankton in $\mathrm{NPG}_{\mathrm{W}}$ and $\mathrm{NPG}_{\mathrm{E}}$ were more susceptible to the ambient light than phytoplankton in the other regions. $\mathrm{NPG}_{\mathrm{W}}$ and $\mathrm{NPG}_{\mathrm{E}}$ together had 50 to $60 \%$ lower FRR-based parameters, and 40 to $60 \%$ lower ${ }^{14} \mathrm{C}$-based parameters, as compared to KUR, ECS and SOJ combined (Fig. 5).

The level of insolation was directly related to the stationwise variation in $\mathrm{E}\left(\mathrm{F}_{\mathrm{q}}{ }^{\prime} / \mathrm{F}_{\mathrm{m}}{ }^{\prime}\right), \mathrm{E}\left(\mathrm{F}_{\mathrm{q}}{ }^{\prime} / \mathrm{F}_{\mathrm{v}}{ }^{\prime}\right)$ and $\mathrm{E}\left(\mathrm{F}_{\mathrm{v}}{ }^{\prime} / \mathrm{F}_{\mathrm{m}}{ }^{\prime}\right)$ (Table 3). Phytoplankton did not appear to compensate for the variation in $\mathrm{E}_{\mathrm{d}}(0-)$ by adjusting the light levels, i.e. the depths, at which $\mathrm{F}_{\mathrm{q}}{ }^{\prime} / \mathrm{F}_{\mathrm{m}}{ }^{\prime}, \mathrm{F}_{\mathrm{q}}{ }^{\prime} / \mathrm{F}_{\mathrm{v}}{ }^{\prime}$ or $\mathrm{F}_{\mathrm{v}}{ }^{\prime} / \mathrm{F}_{\mathrm{m}}{ }^{\prime}$ would start to decrease, but rather these depths appeared to be quite constant. This result seems rather unexpected taking into account the fast response times of the fluorescence induction parameters. Even though our statistical analysis failed to reveal the combined effect of $E_{d}(0-)$ and $K_{a v}$ governing the variation in $\mathrm{E}\left(\mathrm{F}_{\mathrm{q}}{ }^{\prime} / \mathrm{F}_{\mathrm{m}}{ }^{\prime}\right), \mathrm{E}\left(\mathrm{F}_{\mathrm{q}}{ }^{\prime} / \mathrm{F}_{\mathrm{v}}{ }^{\prime}\right)$ and $\mathrm{E}\left(\mathrm{F}_{\mathrm{v}}{ }^{\prime} / \mathrm{F}_{\mathrm{m}}{ }^{\prime}\right)$, this is what most probably occurred. 
The water column properties $\mathrm{K}_{\mathrm{av}}$ and $\mathrm{z}_{\mathrm{SML}}$ best explained the stationwise variation in the ${ }^{14} \mathrm{C}$-based surface parameters $\mathrm{E}_{\mathrm{k}}$ (surface) and $\mathrm{E}$ ( $\mathrm{P}_{\max }$ surface) (Table 3). $\mathrm{K}_{\mathrm{av}}$ was directly and $\mathrm{z}_{\mathrm{SML}}$ inversely related to the surface parameters. The shallower SML led to a higher average light environment, and phytoplankton acclimated to higher light with higher $\mathrm{E}_{\mathrm{k}}$ (surface) and $\mathrm{E}\left(\mathrm{P}_{\max }\right.$ surface $) . \mathrm{K}_{\mathrm{av}}$ and the surface parameters were probably intercorrelated, being affected by the taxonomic structure of phytoplankton that varied markedly, e.g. between the oceanic regions and the shelf seas. The light history of phytoplankton, i.e. the ratio of $\mathrm{z}_{\mathrm{eu}}$ to $\mathrm{z}_{\mathrm{SML}}$ was directly related to the stationwise variation in the deep parameters $E_{k}$ (deep) and $\mathrm{E}\left(\mathrm{P}_{\max }\right.$ deep $)$. A higher ratio, i.e. a smaller time window for phytoplankton to spend in low light, led to higher $\mathrm{E}_{\mathrm{k}}(\mathrm{deep})$ and $\mathrm{E}\left(\mathrm{P}_{\max }\right.$ deep). This result is in concert with our conclusion that, in general, phytoplankton were able to photoacclimate in the near-surface domain (see 'Discussion').

\section{DISCUSSION}

Frequently, nutrient status has an overriding effect, compared to the light environment, in controlling phytoplankton physiology, and hence, their photochemistry (Kolber et al. 1988, Sciandra et al. 1997), but only within a certain degree of variability in the light regime. When cells move or are moved closer to the surface along the exponentially increasing light gradient, the overall control of the nutrient field on photochemistry becomes challenged by photoacclimation and photoinhibition (Geider et al. 1993). The present study was designed to provide a short time-exposure picture of the photochemical properties of phytoplankton by means of fluorescence induction, and the data collected suggest that the light field has a major influence on the primary photochemistry.

Any attempt to define the photoacclimative characteristics of phytoplankton is dependent on the rates of vertical mixing and photoacclimation. Phytoplankton will present a vertical gradient in their photoacclimative characteristics only when their photoacclimative rates overrides the mixing rate (Cullen \& Lewis 1988). If this condition is not met, the attempt will be somewhat compromised. Analytical data collected in the present study suggest that, in general, phytoplankton photoacclimated in the near-surface domain. $\overline{\mathrm{a}}_{\mathrm{ph}}$ * increased with depth in the oceanic regions, and $E_{k}$ decreased with depth in all the regions. Variations in these parameters indicate that there was enough time for changes take place, e.g. in the quota and/or composition of the phytoplankton pigmentation. Thus, the evidence of photoacclimation should also be observable with the highly dynamic fluorescence induction tool. This was indeed observed.

\section{Justification of the approach}

Vertical mixing tends to minimize the vertical variation of $\sigma_{\text {PSII }}$ (Kolber et al. 1990). We adopted the approach of Moore et al. (2003) who linked the vertical $\sigma_{\text {PSII }}$ gradient and the dissipation of turbulent kinetic energy describing the vertical mixing rate. The steepness of the vertical $\sigma_{\text {PSII }}$ gradient appeared to be a hyperbolic function of the mixing rate, and the threshold value for the exponential rise in the $\sigma_{\text {PSII }}$ gradient against the gradually diminishing mixing was $\sim 4 \AA \mathrm{q}^{-1}$ $\mathrm{m}^{-1}$. Values of the $\sigma_{\mathrm{PSII}}$ gradient higher than this would typically suggest the occurrence of acclimative responses. This threshold was met at all the stations in $\mathrm{NPG}_{\mathrm{W}}$ (regional mean $=5.0$ from the surface to 3 optical depths), $\mathrm{NPG}_{\mathrm{E}}($ mean $=6.3), \mathrm{SOJ}($ mean $=5.0)$ and at those stations in KUR with a deep SML (mean = 4.7). In these regions, phytoplankton were apparently able to acclimate to the physicochemical environment. The threshold value was met only occasionally in ECS (mean $=3.3$ ) and not at all at stations in KUR with a shallow SML. Interestingly, at those stations where the threshold value was missed, the ratio of $z_{\text {eu }}$ to $z_{S M L}$ was above unity, meaning that phytoplankton resident within the SML were spending all their time within the photic zone. These shallow-mixed $\left(\mathrm{z}_{\mathrm{SML}}<30 \mathrm{~m}\right)$ stations apparently had so high an average light environment that $\sigma_{\text {PSII }}{ }^{\prime}$ was not a reliable index for the extent of the acclimative responses.

Although the $\sigma_{\mathrm{PSII}}$ ' data did not prove for the presence of acclimation at all the stations, the $\mathrm{F}_{\mathrm{q}}{ }^{\prime} / \mathrm{F}_{\mathrm{m}}{ }^{\prime}$ and $\mathrm{F}_{\mathrm{v}}{ }^{\prime} / \mathrm{F}_{\mathrm{m}}{ }^{\prime}$ data did. A near-surface decrease in $\mathrm{F}_{\mathrm{q}}{ }^{\prime} / \mathrm{F}_{\mathrm{m}}{ }^{\prime}$ and $F_{\mathrm{v}}{ }^{\prime} / \mathrm{F}_{\mathrm{m}}{ }^{\prime}$ was observed everywhere, regardless of the tendency of effective mixing to reduce the magnitude of the near-surface PECE decrease (Oliver et al. 2003). A near-surface decrease in $F_{\mathrm{q}}{ }^{\prime} / \mathrm{F}_{\mathrm{m}}{ }^{\prime}$ and $\mathrm{F}_{\mathrm{v}}{ }^{\prime} / \mathrm{F}_{\mathrm{m}}{ }^{\prime}$ was observed regardless of the fact that $\mathrm{NPG}_{\mathrm{W}}, \mathrm{NPG}_{\mathrm{E}}$, and KUR did not have any clear nutricline in the upper $100 \mathrm{~m}$, and that the nutricline at ECS occurred in a depth interval of 30 to $50 \mathrm{~m}$, below the welldefined SML. The nutricline at SOJ was situated within the SML, being thus a readily available source for nutrients, but, as already noted, our method to assess $\mathrm{Z}_{\mathrm{SML}}$ did not describe the circulation pattern of phytoplankton at SOJ properly. The drastic decreases of $F_{\mathrm{q}}{ }^{\prime} / \mathrm{F}_{\mathrm{m}}{ }^{\prime}$ and $\mathrm{F}_{\mathrm{v}}{ }^{\prime} / \mathrm{F}_{\mathrm{m}}{ }^{\prime}$ towards the surface with the existence of a seemingly unchanged nutrient field strongly indicate that the effect of the light field on phytoplankton photochemistry was at least as influential as the effect of the nutrient field. Based on the 
observations presented, we feel confident in concentrating solely on light as the factor controlling the in situ phytoplankton fluorescence characteristics along the light gradient.

\section{FRR transients in the water column: the fluorescence quenchers $q_{n}$ and $q_{p}$}

Vertical $F_{\mathrm{q}}{ }^{\prime} / \mathrm{F}_{\mathrm{m}}{ }^{\prime}$ and $\mathrm{F}_{\mathrm{v}}{ }^{\prime} / \mathrm{F}_{\mathrm{m}}{ }^{\prime}$ data as the assessment basis

The effects of $q_{p}$ and $q_{n}$ on the PECE decrease were based on the different behaviours of $\mathrm{F}_{\mathrm{q}}{ }^{\prime} / \mathrm{F}_{\mathrm{m}}{ }^{\prime}$ and $\mathrm{F}_{\mathrm{v}}{ }^{1} / \mathrm{F}_{\mathrm{m}}{ }^{\prime}$ in the water column. At a depth below $\delta\left(\mathrm{F}_{\mathrm{q}}{ }^{\prime} / \mathrm{F}_{\mathrm{m}}{ }^{\prime}\right), \mathrm{PECE}$ is not suppressed by the ambient light, but is at its maximum attainable level (Fig. 3). This level is governed by the nutrient regime (e.g. Suzuki et al. 2002, Vaillancourt et al. 2003) and the health of the resident phytoplankton (Babin et al. 1996). PECE starts to decrease as we move upwards and cross the infinitely thin plane parallel to the surface at $\delta\left(\mathrm{F}_{\mathrm{q}}{ }^{\prime} / \mathrm{F}_{\mathrm{m}}{ }^{\prime}\right)$. However, only $\mathrm{q}_{\mathrm{p}}$ depresses PECE below $\delta\left(\mathrm{F}_{\mathrm{v}}{ }^{\prime} / \mathrm{F}_{\mathrm{m}}{ }^{\prime}\right)$. The excitation delivery into the RCII accelerates the PSII photochemistry, and the reducing $Q_{A}$ pool decreases $\mathrm{F}_{\mathrm{q}}{ }^{\prime} / \mathrm{F}_{\mathrm{m}}{ }^{\prime}$. Finally, we will arrive at $\delta\left(\mathrm{F}_{\mathrm{v}}{ }^{\prime} / \mathrm{F}_{\mathrm{m}}{ }^{\prime}\right)$, where the excitation delivery into RCII becomes so pronounced that the electron transport chain components downstream of PSII get over-reduced to a level that triggers the photoprotective $\mathrm{q}_{\mathrm{n}}$ mechanisms. This way, further increases in delivery to RCII will be minimized. However, the reduction of the $\mathrm{Q}_{\mathrm{A}}$ pool continues to proceed simultaneously, decreasing $\mathrm{q}_{\mathrm{p}}$ further.

The regionally averaged $\delta\left(\mathrm{F}_{\mathrm{q}}{ }^{\prime} / \mathrm{F}_{\mathrm{m}}{ }^{\prime}\right)$ was situated at or deeper than $\mathrm{z}_{\mathrm{eu}}$ (Table 2), which appears to contradict our statement of light being the factor controlling the in situ phytoplankton fluorescence characteristics. Kirk's (2003) approach for calculating $\mathrm{K}_{\mathrm{av}}$, and hence, $\mathrm{z}_{\mathrm{eu}}$, gives pronounced weight to the optical properties of the upper layers of the water column. If, for instance, phytoplankton inhabit the near-surface layer in great numbers, the corresponding $K_{d}$ values will bend $K_{a v}$ higher and decrease $z_{\text {eu }}$. If we had calculated $K_{a v}$ simply as a linear regression coefficient of $\ln \left(\mathrm{E}_{\mathrm{d}}\right)$ from the surface to $z_{e u}, K_{a v}$ would have decreased and $\mathrm{z}_{\text {eu }}$ increased on average by $22 \%$. This would have rectified 6 out of the 10 stations that had $\delta\left(\mathrm{F}_{\mathrm{q}}{ }^{\prime} / \mathrm{F}_{\mathrm{m}}{ }^{\prime}\right)$ below $\mathrm{z}_{\mathrm{eu}}$.

We calculated $\delta\left(\mathrm{F}_{\mathrm{q}}{ }^{\prime} / \mathrm{F}_{\mathrm{v}}{ }^{\prime}\right)$ as the depth corresponding to the onset of the decrease of $F_{\mathrm{q}}{ }^{\prime} / \mathrm{F}_{\mathrm{v}}{ }^{\prime}$. The criterion used was analogous to $\delta\left(\mathrm{F}_{\mathrm{v}}{ }^{\prime} / \mathrm{F}_{\mathrm{m}}{ }^{\prime}\right)$, namely the depth at which the upper $95 \% \mathrm{CI}$ of $\mathrm{F}_{\mathrm{q}}{ }^{\prime} / \mathrm{F}_{\mathrm{v}}{ }^{\prime}$ equals $\mathrm{F}_{\mathrm{q}}{ }^{\prime} / \mathrm{F}_{\mathrm{v}}{ }^{\prime}$ at its maximum value. Theoretically, $\delta\left(\mathrm{F}_{\mathrm{q}}{ }^{\prime} / \mathrm{F}_{\mathrm{m}}{ }^{\prime}\right)$ and $\delta\left(\mathrm{F}_{\mathrm{q}}{ }^{\prime} / \mathrm{F}_{\mathrm{v}}{ }^{\prime}\right)$ should co-occur. We found that this happened in $\mathrm{NPG}_{\mathrm{W}}, \mathrm{ECS}$ and SOJ, but not in $\mathrm{NPG}_{\mathrm{E}}$ or KUR (paired $t$-test for $\delta\left(\mathrm{F}_{\mathrm{q}}{ }^{\prime} / \mathrm{F}_{\mathrm{m}}{ }^{\prime}\right)$ and $\delta\left(\mathrm{F}_{\mathrm{q}}{ }^{\prime} / \mathrm{F}_{\mathrm{v}}{ }^{\prime}\right): \mathrm{NPG}_{\mathrm{E}}, t=14.0, \mathrm{p}<$
0.05; KUR, $\left.t_{2}=4.5, \mathrm{p}<0.05\right) . \mathrm{F}_{\mathrm{q}}{ }^{\prime} / \mathrm{F}_{\mathrm{m}}{ }^{\prime}$ is a 1 -channel parameter, while the empirical formulation of $\mathrm{F}_{\mathrm{q}}{ }^{\prime} / \mathrm{F}_{\mathrm{v}}{ }^{\prime}$ consists of 2 light channel fluorescence yields and a dark channel yield. Thus, slight differences in the outputs of the 2 channels, i.e. features linked to calibration, may have caused the observed discrepancy. The remarkable similarity in the regional averages of $\mathrm{E}\left(\mathrm{F}_{\mathrm{q}}{ }^{\prime} / \mathrm{F}_{\mathrm{m}}{ }^{\prime}\right)$ and $\mathrm{E}\left(\mathrm{F}_{\mathrm{q}}{ }^{\prime} / \mathrm{F}_{\mathrm{v}}{ }^{\prime}\right)$ shows that the first-line PECE decrease was indeed a manifestation of a gradual closure of the RCII pool (Fig. 5). The profoundly different approach, based on P-E style modelling, and not on mere smoothing of the data (Fig. 3), masked the possible calibration effects.

\section{Mutual relation between $\mathrm{q}_{\mathrm{n}}$ and $\mathrm{q}_{\mathrm{p}}$}

Most of the PECE decrease in the near-surface layers was due to $\mathrm{q}_{\mathrm{n} i}$ it was the primary factor depressing PECE in the upper $11 \mathrm{~m}\left(\sim 29 \%\right.$ of the $\mathrm{z}_{\text {eu }}$ study average). In all regions except ECS, the average $\left(\mathrm{q}_{\mathrm{n}} / \mathrm{q}_{\mathrm{tot}}\right)_{\mathrm{v}}$ level varied from 0.4 to 0.6 , suggesting that in that part of the water column where $\mathrm{q}_{\mathrm{n}}$ had an effect, that effect was approximately similar to that of $\mathrm{q}_{\mathrm{p}}$. The average $\left(\mathrm{q}_{\mathrm{n}} / \mathrm{q}_{\mathrm{tot}}\right)_{\mathrm{q}}$ level never reached 0.5 , and either a thick SML (NPG $\mathrm{E}_{\mathrm{E}}$ part of KUR), pronounced light attenuation (ECS) or both (SOJ) led to values $<0.2$. Hence, $q_{p}$ seemed to be the main source of the PECE decrease; the longer the water column concerned, the more influential $\mathrm{q}_{\mathrm{p}}$ became.

Morrison monitored the vertical pattern of the quantum yield of chl a fluorescence in the shelf break area in the NE Atlantic, and concluded that $\mathrm{q}_{\mathrm{n}}$ overrode $\mathrm{q}_{\mathrm{p}}$ as the primary depressing factor of the quantum yield in the upper 6 to $19 \mathrm{~m}$ depending on the station (Mor-

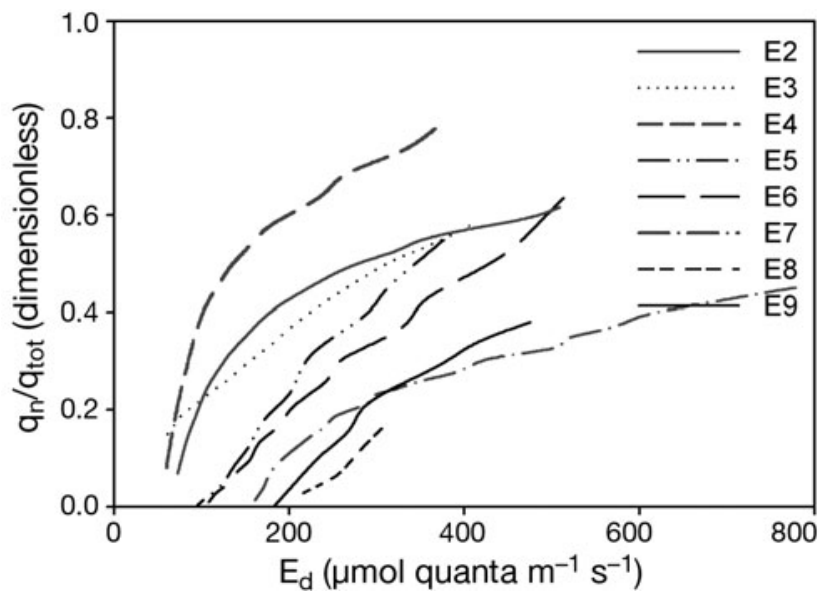

Fig. 6. $\mathrm{q}_{\mathrm{n}} / \mathrm{q}_{\text {tot }}$ as a function of the ambient light, ECS as an example. Depth interval between $\delta\left(\mathrm{F}_{\mathrm{q}}{ }^{\prime} / \mathrm{F}_{\mathrm{m}}{ }^{\prime}\right)$ and $\delta\left(\mathrm{F}_{\mathrm{v}}{ }^{\prime} / \mathrm{F}_{\mathrm{m}}{ }^{\prime}\right)$, having a zero-level $\mathrm{q}_{\mathrm{n}} / \mathrm{q}_{\mathrm{tot}}$, is not presented. $\delta\left(\mathrm{F}_{\mathrm{q}}{ }^{\prime} / \mathrm{F}_{\mathrm{m}}{ }^{\prime}\right)$ and $\mathrm{q}_{\mathrm{n}} / \mathrm{q}_{\text {tot }}$ could not be determined for Stn E1 
rison 2003, their Fig. 8). The stations in that study had $\mathrm{K}_{\mathrm{d}}$ values of 0.11 to 0.19 , being thus comparable to the $\mathrm{K}_{\mathrm{av}}$ levels of the shelf seas in the present study. We did not measure the quantum yield of fluorescence, but rather the bulk fluorescence yield. The closest equivalent to Morrison's (2003) results would therefore be the depth at which $\mathrm{q}_{\mathrm{n}} / \mathrm{q}_{\text {tot }}$ rises above 0.5 . This level was reached at about half of the stations in the shelf seas, and whenever reached, the depth varied from 8 to $12 \mathrm{~m}$, in line with Morrison (2003).

$\mathrm{q}_{\mathrm{n}} / \mathrm{q}_{\text {tot }}$ increased in a curvilinear manner with the ambient light (Fig. 6), but linearly as a function of decreasing depth. Provided that $\mathrm{q}_{\mathrm{n}} / \mathrm{q}_{\text {tot }}$ was by definition about zero at $\delta\left(\mathrm{F}_{\mathrm{v}}{ }^{\prime} / \mathrm{F}_{\mathrm{m}}{ }^{\prime}\right)$, and $\left(\mathrm{q}_{\mathrm{n}} / \mathrm{q}_{\mathrm{tot}}\right)_{\mathrm{v}} \sim 0.5$ as a study average, the linear relationship observed suggests that $\mathrm{q}_{\mathrm{n}} / \mathrm{q}_{\text {tot }}$ would be close to unity below the surface film. However, we could not verify this due to the methodological constraints. Even though the emergence of $\mathrm{q}_{\mathrm{n}}$ above $\delta\left(\mathrm{F}_{\mathrm{v}}{ }^{\prime} / \mathrm{F}_{\mathrm{m}}{ }^{\prime}\right)$ immediately started to increase $\mathrm{q}_{\mathrm{n}} / \mathrm{q}_{\text {tot }}$, the $\mathrm{q}_{\mathrm{p}}$ effect also continued to rise, although more moderately. The RCII pool did not at any time get fully reduced, which is in accordance with the general theory (Falkowski \& Kolber 1993); consequently, $F_{\mathrm{q}}{ }^{\prime} / \mathrm{F}_{\mathrm{m}}{ }^{\prime}$ and $\mathrm{F}_{\mathrm{v}}{ }^{\prime} / \mathrm{F}_{\mathrm{m}}{ }^{\prime}$ did not intersect even at the uppermost sampling depths.

\section{Regional variation}

The $E_{\mathrm{d}}$ at $\delta\left(\mathrm{F}_{\mathrm{v}}{ }^{\prime} / \mathrm{F}_{\mathrm{m}}{ }^{\prime}\right)$ and the $\mathrm{E}_{\mathrm{d}}$ at $\delta\left(\mathrm{F}_{\mathrm{q}}{ }^{\prime} / \mathrm{F}_{\mathrm{m}}{ }^{\prime}\right)$ explained well the variation in $\left(\mathrm{q}_{\mathrm{n}} / \mathrm{q}_{\text {tot }}\right)_{\mathrm{q}}$ for methodological reasons (Table 3$)$. However, the water physics $\left(\mathrm{K}_{\mathrm{av}}\right.$ and, statistically, $\mathrm{z}_{\mathrm{SML}}$ ) truly governed the variation in $\left(\mathrm{q}_{\mathrm{n}} / \mathrm{q}_{\text {tot }}\right)_{\mathrm{q}}$. At the $\mathrm{NPG}_{\mathrm{W}}$ stations, and at least one KUR station, a combination of weak light attenuation (low $\mathrm{K}_{\mathrm{av}}$ ) and shallow SML (low $\mathrm{Z}_{\mathrm{SML}}$ ) explained the highest $\left(\mathrm{q}_{\mathrm{n}} / \mathrm{q}_{\mathrm{tot}}\right)_{\mathrm{q}}$. This combination apparently led phytoplankton to experience a high average light environment, which was reflected in the increased need for the $\mathrm{q}_{\mathrm{n}}$ mechanisms. For NPG ${ }_{W}$, though, this is not the whole story. At these stations, (1) a high $\left(\mathrm{q}_{\mathrm{n}} / \mathrm{q}_{\text {tot }}\right)_{\mathrm{q}}$ and a low $\mathrm{E}\left(\mathrm{F}_{\mathrm{v}}{ }^{\prime} / \mathrm{F}_{\mathrm{m}}{ }^{\prime}\right)$ suggest the $\mathrm{q}_{\mathrm{n}}$ mechanisms were induced at relatively low light levels; (2) the small vertical distance between $E\left(F_{\mathrm{q}}{ }^{\prime} / \mathrm{F}_{\mathrm{m}}{ }^{\prime}\right)$ and $\mathrm{E}\left(\mathrm{F}_{\mathrm{v}}{ }^{\prime} / \mathrm{F}_{\mathrm{m}}{ }^{\prime}\right)$ suggests there was a rather a small vertical window in which photochemistry was solely responsible for the PECE decrease (Fig. 5); and (3) the ratio of $\mathrm{E}\left(\mathrm{F}_{\mathrm{q}}{ }^{\prime} / \mathrm{F}_{\mathrm{v}}{ }^{\prime}\right)$ to $\mathrm{E}_{\mathrm{k}}$ (surface) in $\mathrm{NPG}_{\mathrm{E}}$, and hence probably also in $\mathrm{NPG}_{\mathrm{W}}$, was low, indicating a small difference between the optimal PAR region for the phytoplankton photochemistry and the overall photosynthetic process (Fig. 5). All this indicates that phytoplankton in $\mathrm{NPG}_{\mathrm{W}}$ had the lowest observed intrinsic light management potential.

The $\mathrm{NPG}_{\mathrm{E}}$ stations had a deep SML (high $\mathrm{z}_{\mathrm{SML}}$ ) that seemed to decrease $\left(\mathrm{q}_{\mathrm{n}} / \mathrm{q}_{\text {tot }}\right)_{\mathrm{q}}$. The ECS stations, in turn, had a shallow SML that should increase $\left(\mathrm{q}_{\mathrm{n}} / \mathrm{q}_{\mathrm{tot}}\right)_{\mathrm{q}}$, but also attenuated light strongly, something that likely counteracted the situation (Table 2). SOJ attenuated light strongly and had a deep SML, which suggests it likely had the lowest average light environment for phytoplankton to experience, provided they were continuously circulating within the SML.

In practice, $\left(\mathrm{q}_{\mathrm{n}} / \mathrm{q}_{\mathrm{tot}}\right)_{\mathrm{v}}$ can be thought of as a proxy for the steepness of the rise in the $q_{n}$ effect above $\delta\left(F_{v}{ }^{\prime} / F_{m}{ }^{\prime}\right)$. This steepness depends on $z_{S M L}$, i.e. the average light environment in the SML (Table 3). Although the insolation failed to statistically explain the variation in $\left(\mathrm{q}_{\mathrm{n}} / \mathrm{q}_{\mathrm{tot}}\right)_{\mathrm{v}}$, the effects of $\mathrm{z}_{\mathrm{SML}}$ and insolation seemed to be additive, as suggested by the highest observed $\left(\mathrm{q}_{\mathrm{n}} / \mathrm{q}_{\text {tot }}\right)_{\mathrm{v}}$ level in ECS. Here, the SML was clearly shallowest, and situated entirely in the euphotic zone (Table 2). ECS thus had probably the highest average light environment for phytoplankton to experience.

\section{FRR transients along the light gradient}

We assessed the vertical variation in the fluorescence induction parameters using 2 completely different approaches. The approach based on the locally weighted regression analysis is a relatively soft treatment and provided us with the parameters $\delta\left(\mathrm{F}_{\mathrm{v}}{ }^{\prime} / \mathrm{F}_{\mathrm{m}}{ }^{\prime}\right)$, $\delta\left(\mathrm{F}_{\mathrm{q}}{ }^{\prime} / \mathrm{F}_{\mathrm{m}}{ }^{\prime}\right)$ and $\left(\mathrm{q}_{\mathrm{n}} / \mathrm{q}_{\mathrm{tot}}\right)$, which are closely linked to the original data. The exponential fluorescence-irradiance $(\mathrm{F}-\mathrm{E})$ modelling based on the $\mathrm{P}-\mathrm{E}$ relation of Webb et al. (1974) makes considerable assumptions concerning the behaviour of the data. The fluorescence induction based light response parameters discussed below should be compared only to the ${ }^{14} \mathrm{C}$ based P-E parameters.

$$
\text { Roles of } \mathrm{E}\left(\mathrm{F}_{\mathrm{q}}{ }^{\prime} / \mathrm{F}_{\mathrm{m}}{ }^{\prime}\right) \text { and } \mathrm{E}\left(\mathrm{F}_{\mathrm{v}}{ }^{\prime} / \mathrm{F}_{\mathrm{m}}{ }^{\prime}\right)
$$

Beneath $\mathrm{E}\left(\mathrm{F}_{\mathrm{q}}{ }^{\prime} / \mathrm{F}_{\mathrm{m}}{ }^{\prime}\right)$, only the nutrient status controls PECE. Here, growth-limiting micro- or macronutrients prevent, most of the time, $F_{\mathrm{q}}{ }^{\prime} / \mathrm{F}_{\mathrm{m}}{ }^{\prime}$ and $\mathrm{F}_{\mathrm{v}}{ }^{\prime} / \mathrm{F}_{\mathrm{m}}{ }^{\prime}$ from reaching the highest attainable levels observed in nature (Boyd \& Abraham 2001). $E\left(F_{q}{ }^{\prime} / F_{m}{ }^{\prime}\right)$ describes the specific light level at which the light, in addition to the nutrient regime, starts to play a pronounced role in the control of PECE.

At light levels above $\mathrm{E}\left(\mathrm{F}_{\mathrm{q}}{ }^{\prime} / \mathrm{F}_{\mathrm{m}}{ }^{\prime}\right)$, the effect of light on $\mathrm{PECE}$ increases rapidly, and at $\mathrm{E}\left(\mathrm{F}_{\mathrm{v}}{ }^{\prime} / \mathrm{F}_{\mathrm{m}}{ }^{\prime}\right)$ it ultimately overrides the effect of the nutrient status on PECE. $\mathrm{E}\left(\mathrm{F}_{\mathrm{v}}{ }^{\prime} / \mathrm{F}_{\mathrm{m}}{ }^{\prime}\right)$ was defined as the light level at which the $\mathrm{q}_{\mathrm{n}}$ mechanisms started to play a significant role. At high light levels, such as those above $\mathrm{E}\left(\mathrm{F}_{\mathrm{v}}{ }^{\prime} / \mathrm{F}_{\mathrm{m}}{ }^{\prime}\right)$, state transitions do not play an important role, and photoprotec- 
tion in the form of xanthophyll cycling likely became the predominant tool mitigating the approaching photoinactivation of PSII (Krause \& Jahns 2004, and references therein). In the present study, cyanobacterial taxa dominated the phytoplankton community in the oceanic regions. The lack of the xanthophyll cycle in cyanobacteria was compensated by a down-regulation mechanism that functions in RCII and shares the same biochemical basis as the xanthophyll cycle, i.e. a transthylakoid proton gradient (Larkum 2003).

\section{Relation between $\mathrm{E}_{\mathrm{k}}$ and $\mathrm{E}\left(\mathrm{F}_{\mathrm{q}}{ }^{\prime} / \mathrm{F}_{\mathrm{v}}{ }^{\prime}\right)$}

The first index of the photoacclimative responses met along the light gradient was $\mathrm{E}_{\mathrm{k}}$ (Fig. 5). At $\mathrm{E}_{\mathrm{k}}$, the control of photosynthesis changes from resource (light) limitation to product (reductant) utilization (Sakshaug et al. 1997). The difference between $E_{k}$ (surface) and $\mathrm{E}_{\mathrm{k}}(\mathrm{deep})$ was a manifestation of the photoacclimation: phytoplankton in the upper $10 \mathrm{~m}$ were acclimated to approximately 2-fold higher light intensities than phytoplankton below a depth of $10 \mathrm{~m}$.

For the entire study, the ratio $\mathrm{E}\left(\mathrm{F}_{\mathrm{q}}{ }^{\prime} / \mathrm{F}_{\mathrm{v}}{ }^{\prime}\right)$ to $\mathrm{E}_{\mathrm{k}}$ (surface) was $\sim 1.4$ for $\mathrm{NPG}_{\mathrm{E}}$, and $\sim 2.4$ for KUR, ECS and SOJ combined (Fig. 5). It is reasonable to expect that the photosynthetic apparatus keeps the $\mathrm{Q}_{\mathrm{A}}$ pool at its most attainable oxidized state, and consequently $\mathrm{F}_{\mathrm{q}}{ }^{\prime} / \mathrm{F}_{\mathrm{m}}{ }^{\prime}$ as close to $\mathrm{F}_{\mathrm{v}}{ }^{\prime} / \mathrm{F}_{\mathrm{m}}{ }^{\prime}$ as possible, as long as the photosynthesis is resource-limited by the incoming light. This result suggests, however, that this virtual steady-state would continue to almost 2.5-fold higher light levels than that at which photosynthesis works in an energetically balanced situation $\left(\mathrm{NPG}_{\mathrm{E}}\right.$ was an exception to the rule).

The redox state of the $\mathrm{Q}_{\mathrm{A}}$ pool, as estimated by $\mathrm{F}_{\mathrm{q}}{ }^{\prime} / \mathrm{F}_{\mathrm{v}}{ }^{\prime}$, is controlled by the excitation delivery into the RCII pool, but also by the $\mathrm{Q}_{\mathrm{A}}$ reoxidation rate, and, ultimately, by the potential of the $\mathrm{C}$ fixation process to utilize the reducing power (Baker \& Oxborough 2003, Moore et al. 2006). The potential of the dark reactions to utilize the reducing power has biophysical limits that are not linked to the production of the reducing power. Therefore, at some point along the ambient light gradient, the fraction of the closed RCs starts to accumulate. $\mathrm{E}\left(\mathrm{F}_{\mathrm{q}}{ }^{\prime} / \mathrm{F}_{\mathrm{v}}{ }^{\prime}\right)$ is a diagnostic of this light level. $\mathrm{E}\left(\mathrm{F}_{\mathrm{q}}{ }^{\prime} / \mathrm{F}_{\mathrm{v}}{ }^{\prime}\right)$ bears a certain analogy to its ${ }^{14} \mathrm{C}$ counterpart $\mathrm{E}_{\mathrm{k}}$, at which the light and dark reactions are energetically in balance with one another (Sakshaug et al. 1997). At $E\left(\mathrm{~F}_{\mathrm{q}}{ }^{\prime} / \mathrm{F}_{\mathrm{v}}{ }^{\prime}\right)$, the inflow rate of energy to the light reactions and its outflow in the form of the usage of the electron transport products are functioning at the highest attainable balanced rate. The difference between $\mathrm{E}\left(\mathrm{F}_{\mathrm{q}}{ }^{\prime} / \mathrm{F}_{\mathrm{v}}{ }^{\prime}\right)$ and $\mathrm{E}_{\mathrm{k}}$, i.e. between the 2 criteria for a perfect balance obtained from 2 completely dif- ferent techniques, shows that the optimal PAR region for photochemistry is much higher than for photosynthesis in general (Smyth et al. 2004).

Relation between $\mathrm{E}\left(\mathrm{F}_{\mathrm{v}}{ }^{\prime} / \mathrm{F}_{\mathrm{m}}{ }^{\prime}\right)$ and $\mathrm{E}\left(\mathrm{P}_{\max }\right)$

$\mathrm{E}\left(\mathrm{F}_{\mathrm{v}}{ }^{\prime} / \mathrm{F}_{\mathrm{m}}{ }^{\prime}\right)$ was in close agreement with $\mathrm{E}\left(\mathrm{P}_{\max }\right)$, typically with $\mathrm{E}\left(\mathrm{P}_{\max }\right.$ surface $)$, but in the ECS also with $\mathrm{E}\left(\mathrm{P}_{\max }\right.$ deep) (Fig. 5). The highest attainable biomassspecific photosynthetic rates were seemingly reached close to the ambient light level at which the photoprotective measures first became necessary. This conclusion fits nicely with contemporary knowledge of the physiological basis of the P-E dependence. The emergence of the $\mathrm{q}_{\mathrm{n}}$ mechanisms was located at the point at which the P-E curve enters the plateau phase. This phase allows production to remain close to $\mathrm{P}_{\max }$ over a wide light interval, regardless of further reductions in the $Q_{A}$ pool (i.e. changes in the $q_{p}$ effect) and the advancing $\mathrm{q}_{\mathrm{n}}$ effect. The primary photochemistry has no direct control over photosynthesis at this stage, because the rate limiting step in the light saturation of photosynthesis is found in the constituents and processes of the dark reactions (Henley 1993, Behrenfeld et al. 2004). Here, the combined effect of the emerging photoinhibition and the mitigating photoprotective measures had no effect on $\mathrm{P}_{\max }$ due to the excess capacity of PSII electron turnover (sensu Behrenfeld et al. 1998). $P_{\max }$ is maintained regardless of the progressive photoinactivation of the PSII pool until the light level is reached, at which this capacity is exhausted. At this point, the limitation of photosynthesis returns to the light reactions, and consequently, the onset of photoinhibition is noticed in the $\mathrm{P}-\mathrm{E}$ curve.

The notion that $P_{\max }$ is reached at $E\left(\mathrm{~F}_{\mathrm{v}}{ }^{\prime} / \mathrm{F}_{\mathrm{m}}{ }^{\prime}\right)$ is far from being accepted as a universal rule, and has still to be tested further, as indeed does our entire approach. However, if this relationship proves to be a more general feature of phytoplankton ecology, it has the potential to become a convenient and unbiased way of determining the depth and light level of $\mathrm{P}_{\max }$ in the water column.

Suggett et al. (2003) determined $\mathrm{F}_{\mathrm{q}}{ }^{\prime} / \mathrm{F}_{\mathrm{m}}{ }^{\prime}-\mathrm{E}$ curves for laboratory cultures representing various systematic groups. They found that the light level to reduce the plastoquinone $(\mathrm{PQ})$ pool was 3 times higher than that at which $\mathrm{F}_{\mathrm{q}}{ }^{\prime} / \mathrm{F}_{\mathrm{m}}{ }^{\prime}$ started to decrease. The observed $\mathrm{E}\left(\mathrm{F}_{\mathrm{v}}{ }^{\prime} / \mathrm{F}_{\mathrm{m}}{ }^{\prime}\right)$ in the present study was, on average, 2.5fold higher than $\mathrm{E}\left(\mathrm{F}_{\mathrm{q}}{ }^{\prime} / \mathrm{F}_{\mathrm{m}}{ }^{\prime}\right)$ (Fig. 5). This value is close enough to that of Suggett et al. (2003) (their model relating $\mathrm{F}_{\mathrm{q}}{ }^{\prime} / \mathrm{F}_{\mathrm{m}}{ }^{\prime}$ and $\mathrm{E}_{\mathrm{d}}$ was also exponential) to suggest that the photoprotective measures are induced close to the situation where the PQ pool gets reduced. More importantly, markedly low $\mathrm{F}_{\mathrm{q}}{ }^{\prime} / \mathrm{F}_{\mathrm{m}}{ }^{\prime}$ levels $(<0.2$, 
interpreted from a graphical presentation, data not shown) accompany this redox state of the PQ pool (Suggett et al. 2003). An $F_{q}^{\prime} / F_{m}$ ' level this low indicates severe light or nutrient stress (DiTullio et al. 2005, Moore et al. 2005), and suggests that phytoplankton tend to take photoprotective measures only when the photosynthetic system's functional integrity is severely compromised. Before these measures take place, the gradual closure of the RCII pool is the predominant factor depressing PECE. Once these measures occur, the $q_{n}$ mechanisms dissipating excess energy have the potential to retard further closure of the RCII pool (Krause \& Jahns 2004). Hence, $q_{p}$ and the $q_{n}$ mechanisms seem to function in a reciprocal way in depressing PECE.

Taken together, the nutrient regime is the overall main controller of the photochemical efficiency of PSII, thus setting the highest attainable PECE levels. Ambient light seems to function within these frames, and begins to play an important role in the upper parts of the water column. This zone is characterized by drastic reductions in the parameters retrieved from fluorescence induction data. Eventually, in the near-surface layers, ambient light becomes the predominant factor controlling the primary photochemistry.

\section{CONCLUSIONS}

We have presented 2 approaches to assess the effect of varying ambient light in the water column on those photoacclimative characteristics of the intact phytoplankton that can be monitored by chl a fluorescence induction. These approaches were based on highprecision data, and allowed us to identify various photoacclimative responses occurring either in the water column or with respect to the light gradient.

The depth-dependent approach provides a parameter having its basis in the primary photochemistry, that is, the photochemical quenching of the chl a fluorescence. It is not dependent on the vertical mixing rates within the water column, but directly linked to the light field except in the near-surface layers, where the nonphotochemical quenching of the chl a fluorescence starts to play a pronounced role. This parameter has its basis in phytoplankton photoacclimation and/or photoinhibition, and is subject to the generally acknowledged perception that whenever the photoacclimative characteristics of the water column phytoplankton are assessed, the success of this attempt is dependent on the rates of vertical mixing being lower than the photoacclimative rates. These 2 parameters made it possible to identify the effects of the primary photochemistry and photoprotective and/or photoinhibitory actions on the photochemical energy conversion efficiency.
The light-dependent approach was based on the search for the dependence of the fluorescence induction parameters on variations in the ambient light. The principles of exponential P-E modelling were used as a guideline. Our approach provided, if not a snapshot, at least a rather short time-exposure picture of how phytoplankton optimize their life in an environment in which light attenuates exponentially and becomes spectrally biased in the water column, and in which the light level changes on several temporal scales, from the order of fractions of a second to a diurnal scale of several hours. Thus, photoacclimative processes are not optimally described by more static criteria (Blanchard et al. 2004), such as P-E curves based on the photosynthetic gas exchange with prolonged incubation periods. These criteria have to be supplemented with approaches that can react to this huge challenge of an ever-varying light field, i.e. with approaches that reveal the light-dependence of the fluorescence induction parameters. The approaches presented here have the potential to enhance micro-scale studies on the responses of phytoplankton towards their physicochemical environment.

Acknowledgements. This article was realised with the financial support of the Maj and Tor Nessling Foundation, the Onni Talas Foundation, the Finnish Institute of Marine Research for M.R. and the NASA SIMBIOS contract NAS5-01002 for B.G.M. The authors thank O. Kopelevich, Y. Mino, T. Horiuchi, and S. Storms for their involvement in the water sampling and measurements. The authors are in debt to NOAA for the premises that were made available on board the NOAA-vessel RV 'Ronald H. Brown' on her voyage, and for the efforts of her crew. The constructive dialogue with the anonymous reviewers strengthened the manuscript.

\section{LITERATURE CITED}

Allen JF (1992) Protein phosphorylation in regulation of photosynthesis. Biochim Biophys Acta 1098:275-335

> Babin M, Morel A, Claustre H, Bricaud A, Kolber Z, Falkowski PG (1996) Nitrogen- and irradiance-dependent variations of the maximum quantum yield of carbon fixation in eutrophic, mesotrophic and oligotrophic marine systems. Deep-Sea Res 43:1241-1272

Baker NR, Oxborough K (2003) Chlorophyll fluorescence as a probe of photosynthetic productivity. In: Papageorgiou CG, Govindgee AD (eds) Chlorophyll fluorescence: a signature of photosynthesis, Vol 19. Kluwer Academic Press, Dordrecht, p 65-82

Barranguet C, Kronkamp J (2000) Estimating primary production rates from photosynthetic electron transport in estuarine microphytobenthos. Mar Ecol Prog Ser 204: 39-52

Behrenfeld MJ, Kolber ZS (1999) Widespread iron limitation of phytoplankton in the south Pacific Ocean. Science 283:840-843

Behrenfeld MJ, Prasil O, Kolber ZS, Babin M, Falkowski PG (1998) Compensatory changes in photosystem II turnover rates protect photosynthesis from photoinhibition. 
Photosynth Res 58:259-268

Behrenfeld MJ, Prasil O, Babin M, Bruyant F (2004) In search of physiological basis for covariations in light-limited and light-saturated photosynthesis. J Phycol 40:4-25

Bilger W, Björkman O (1990) Role of the xanthophyll cycle in photoprotection elucidated by measurements of lightinduced absorption changes, fluorescence and photosynthesis in Hedera canadiensis. Photosynth Res 25:173-185

Blanchard GF, Guarini JM, Dang C, Richard P (2004) Characterizing and quantifying photoinhibition in intertidal microphytobenthos. J Phycol 40:692-696

Bonaventura C, Myers J (1969) Fluorescence and oxygen evolution in Chlorella pyredoinosa. Biochim Biophys Acta 189:366-383

Boyd PW, Abraham ER (2001) Iron-mediated changes in phytoplankton photosynthetic competence during SOIREE. Deep-Sea Res Part II 48:2529-2550

Bradbury M, Baker NR (1981) Analysis of the slow phases of the in vivo chlorophyll fluorescence induction curve. Changes in the redox state of photosystem II electron acceptors and fluorescence emission from photosystems I and II. Biochim Biophys Acta 635:542-551

Bradbury M, Baker NR (1984) A quantitative determination of photochemical and non-photochemical quenching during the slow phase of the chlorophyll fluorescence induction curve of bean leaves. Biochim Biophys Acta 765:275-281

Campbell D, Hurry V, Clarke AK, Gustafsson P, Öquist G (1998) Chlorophyll fluorescence analysis of cyanobacterial photosynthesis and acclimation. Microbiol Mol Biol Rev 62:667-683

Cleveland WS (1979) Robust locally weighted regression and smoothing scatterplots. J Am Stat Assoc 74:829-836

Cullen JJ, Lewis MR (1988) The kinetics of algal photoadaptation in the context of vertical mixing. J Plankton Res 10:1039-1063

Demmig-Adams B (1990) Carotenoids and photoprotection in plants: a role for the xanthophyll zeaxanthin. Biochim Biophys Acta 1020:1-24

DiTullio GR, Geesey ME, Maucher JM, Alm MB, Riseman SF, Bruland KW (2005) Influence of iron on algal community composition and physiological status in the Peru upwelling system. Limnol Oceanogr 50:1887-1907

Dubinsky Z, Falkowski PG, Wyman K (1986) Light harvesting and utilization by phytoplankton. Plant Cell Physiol 27: 1335-1349

Falkowski PG, Kolber Z (1993) Estimation of phytoplankton photosynthesis by active fluorescence. ICES Mar Sci Symp 197:92-103

Falkowski PG, Raven JA (1997) Aquatic photosynthesis. Blackwell Science

Figueroa FL, Conde-Álvarez R, Gómez I (2003) Relations between electron transport rates determined by pulse amplitude modulated chlorophyll fluorescence and oxygen evolution in macroalgae under different light conditions. Photosynth Res 75:259-275

Fujiki T, Suzue T, Kimoto H, Saino T (2007) Photosynthetic electron transport in Dunaniella tertiolecta (Chlorophyceae) measured by fast repetition rate fluorometry: relation to carbon assimilation. J Plankton Res 29:199-208

Geider RJ, Greene RM, Kolber Z, MacIntyre HL, Falkowski PG (1993) Fluorescence assessment of maximum quantum efficiency of photosynthesis in the western North Altantic. Deep-Sea Res 40:1205-1224

Genty B, Briantais JM, Baker NR (1989) The relationship between the quantum yield of photosynthetic electron transport and quenching of chlorophyll fluorescence. Biochim Biophys Acta 990:87-92
Genty B, Harbinson J, Briantais JM, Baker NR (1990) The relationship between non-photochemical quenching of chlorophyll fluorescence and the rate of photosystem 2 photochemistry in leaves. Photosynth Res 25:249-257

Gorbunov MY, Kolber ZS, Lesser MP, Falkowski PG (2001) Photosynthesis and photoprotection in symbiotic corals. Limnol Oceanogr 46:75-85

Henley WJ (1993) Measurement and interpretation of photosynthetic light-response curves in algae in the context of photoinhibition and diel changes. J Phycol 29:729-739

> Hiscock MR, Marra J, Smith WO Jr, Goericke R and others (2003) Primary productivity and its regulation in the Pacific sector of the Southern Ocean. Deep-Sea Res 50: $533-558$

Hofstraat JW, Peeters JCH, Snel JFH, Geel C (1994) Simple determination of photosynthetic efficiency and photoinhibition of Dunaliella tertiolecta by saturating pulse fluorescence measurements. Mar Ecol Prog Ser 103:187-196

Horton P, Hague A (1988) Studies on the induction of chlorophyll fluorescence in isolated barley protoplasts. IV Resolution of non-photochemical quenching. Biochim Biophys Acta 932:107-115

Jerlov NG (1976) Marine optics, Vol 14. Elsevier, Amsterdam

Kirk JTO (2003) The vertical attenuation of irradiance as a function of the optical properties of the water. Limnol Oceanogr 48:9-17

Kishino M, Takahashi N, Okami N, Ichimura S (1985) Estimation of the spectral absorption coefficients of phytoplankton in the sea. Bull Mar Sci 37:265-275

Kolber ZS, Falkowski PG (1993) Use of active fluorescence to estimate phytoplankton photosynthesis in situ. Limnol Oceanogr 38:1646-1665

Kolber ZS, Zehr J, Falkowski PG (1988) Effects of growth irradiance and nitrogen limitation on photosynthetic energy conversion in photosystem II. Plant Physiol 88:923-929

Kolber ZS, Wyman KD, Falkowski PG (1990) Natural variability in photosynthetic energy conversion efficiency: a field study in the Gulf of Maine. Limnol Oceanogr 35:72-79

Kolber ZS, Prá?il O, Falkowski PG (1998) Measurements of variable fluorescence using fast repetition rate techniques: defining methodology and experimental protocols. Biochim Biophys Acta 1367:88-106

Krause GH, Jahns P (2004) Non-photochemical energy dissipation determined by chlorophyll fluorescence quenching: characterization and function. In: Papageorgiou CG, Govindjee (eds) Chlorophyll a fluorescence: a signature of photosynthesis, Vol 19. Springer, Dordrecht, p 463-495

> Krause GH, Weis E (1991) Chlorophyll fluorescence and photosynthesis: the basics. Annu Rev Plant Physiol Plant Mol Biol 42:313-349

Larkum AWD (2003) Light-harvesting systems of algae. In: Larkum AWD, Douglas SE, Raven JA (eds) Photosynthesis in algae, Vol 14. Kluwer Academic Publishers, Dordrecht, p 277-304

Lavergne J, Leci E (1993) Properties of inactive photosystem II centers. Photosynth Res 35:323-343

> Levy O, Dubinsky Z, Schneider K, Achituv Y, Zakai D, Gorbunov MY (2004) Diurnal hysteresis in coral photosynthesis. Mar Ecol Prog Ser 268:105-117

Mitchell BG (1990) Algorithms for determining the absorption coefficient of aquatic particulates using the quantitative filter technique (QFT). In: Spinrad R (ed) Ocean optics X, Vol 1302. SPIE, p 137-148

Moore CM, Suggett D, Holligan PM, Sharples J and others (2003) Physical controls on phytoplankton physiology and production at a shelf sea front: a fast repetition rate fluorometer based study. Mar Ecol Prog Ser 259:29-45 
Moore CM, Lucas MI, Sanders R, Davidson R (2005) Basinscale variability of phytoplankton bio-optical characteristics in relation to bloom state and community structure in the northeast Atlantic. Deep-Sea Res 52:401-419

Moore CM, Suggett DJ, Hickman AE, Kim YN and others (2006) Phytoplankton photoacclimation and photoadaptation in response to environmental gradients in a shelf sea. Limnol Oceanogr 51:936-949

Morel A, Prieur L (1977) Analysis of variations in ocean color. Limnol Oceanogr 22:709-722

Morrison JR (2003) In situ determination of the quantum yield of phytoplankton chlorophyll a fluorescence: a simple algorithm, observations, and a model. Limnol Oceanogr 48:618-631

Neale PJ (1987) Algal photoinhibition and photosynthesis in the aquatic environment. In: Kyle DJ, Osmond CB, Arntzen CJ (eds) Photoinhibition. Elsevier, Amsterdam, p 39-65

Oliver RL, Whittington J, Lorenz Z, Webster IT (2003) The influence of vertical mixing on the photoinhibition of variable chlorophyll a fluorescence and its inclusion in a model of phytoplankton photosynthesis. J Plankton Res 25:1107-1129

> Oxborough K (2004) Imaging of chlorophyll a fluorescence: theoretical and practical aspects of an emerging technique for the monitoring of photosynthetic performance. J Exp Bot 55:1195-1205

Raateoja M (2004) Fast repetition rate fluorometry (FRRF) measuring phytoplankton productivity: a case study at the entrance to the Gulf of Finland. Boreal Environ Res 9: 263-276

Raateoja M, Seppälä J, Kuosa H (2004a) Bio-optical modelling of primary production in the SW Finnish coastal zone, Baltic Sea: fast repetition rate fluorometry in Case 2 waters. Mar Ecol Prog Ser 267:9-26

Raateoja M, Seppälä J, Ylöstalo P (2004b) Fast repetition rate fluorometry is not applicable to studies of filamentous cyanobacteria from the Baltic Sea. Limnol Oceanogr 49:1006-1012

Sakshaug E, Bricaud A, Dannonneau Y, Falkowski PG and others (1997) Parameters of photosynthesis: definitions, theory and interpretation of results. J Plankton Res 19: 1637-1670

Sciandra A, Gostan J, Collos Y, Descolas-Gros C and others (1997) Growth-compensating phenomena in continuous cultures of Dunaniella tertiolecta limited simultaneously by light and nitrate. Limnol Oceanogr 42:1325-1339

Smyth TJ, Pemberton KL, Aiken J, Geider RJ (2004) A methodology to determine primary production and phytoplankton photosynthetic parameters from fast repetition rate fluorometry. J Plankton Res 26:1337-1350

Sosik HM, Olson RJ (2002) Phytoplankton and iron limitation of photosynthetic efficiency in the Southern Ocean during late summer. Deep-Sea Res 49:1195-1216

Steemann Nielsen E (1952) The use of radioactive carbon

Editorial responsibility: Graham Savidge,

Portaferry, UK $\left({ }^{14} \mathrm{C}\right)$ for measuring organic production in the sea. $\mathrm{J}$ Cons Int Explor Mer 18:117-140

Strasser RJ, Tsimilli-Michael M, Srivastava A (2004) Analysis of the chlorophyll a fluorescence transient. In: Papageorgiou CG, Govindjee (eds) Chlorophyll a fluorescence: a signature of photosynthesis, Vol 19. Springer, Dordrecht, p 321-362

Suggett DJ, Kraay G, Holligan P, Davey M, Aiken J, Geider RJ (2001) Assessment of photosynthesis in a spring cyanobacterial bloom by use of a fast repetition rate fluorometer. Limnol Oceanogr 46:802-810

Suggett DJ, Oxborough K, Baker NR, MacIntyre H, Kana TM, Geider RJ (2003) Fast repetition rate and pulse amplitude modulation chlorophyll a fluorescence measurements for assessment of photosynthetic electron transport in marine phytoplankton. Eur J Phycol 38:371-384

Suggett DJ, Moore CM, Marañón E, Omachi G, Varela RA, Aiken J, Holligan PM (2006) Photosynthetic electron turnover in the tropical and subtropical Atlantic Ocean. Deep-Sea Res 53:1573-1592

Suzuki K, Liu H, Saino T, Obata H and others (2002) East-west gradients in the photosynthetic potential of phytoplankton and iron concentration in the subarctic Pacific Ocean during the early summer. Limnol Oceanogr 47:1591-1594

Vaillancourt RD, Marra J, Seki MP, Parsons ML, Bidigare RR (2003) Impact of a cyclonic eddy on phytoplankton community structure and photosynthetic competency in the subtropical North Pacific Ocean. Deep-Sea Res 50: 829-847

van Kooten O, Snel JFH (1990) The use of chlorophyll fluorescence nomenclature in plant stress physiology. Photosynth Res 25:147-150

> Vassiliev IR, Prasil O, Wyman KD, Kolber Z, Hanson AKJ, Prentice JE, Falkowski PG (1994) Inhibition of PS II photochemistry by PAR and UV radiation in natural phytoplankton communities. Photosynth Res 42:51-64

- Webb WL, Newton M, Starr D (1974) Carbon dioxide exchange of Alnus rubra: a mathematical model. Oecologia 17:281-291

> Weis E, Berry JA (1987) Quantum efficiency of photosystem II in relation to 'energy-dependent' quenching of chlorophyll fluorescence. Biochim Biophys Acta 894:198-208

Winters G, Loya Y, Röttgers R, Beer S (2003) Photoinhibition of shallow-water colonies of the coral Stylophora pistillata as measured in situ. Limnol Oceanogr 48:1388-1393

Wright SW, Jeffrey SW, Mantoura RFC, Llewellyn CA, Bjornland T, Repeta D, Welschmeyer N (1991) Improved HPLC method for the analysis of chlorophylls and carotenoids from marine phytoplankton. Mar Ecol Prog Ser 77: 183-196

Yamamoto HY, Nakayama TOM (1962) Studies on the light and dark interconversions of leaf xanthophylls. Arch Biochem Biophys 97:168-173

Submitted: May 26, 2008; Accepted: September 25, 2008 Proofs received from author(s): January 28, 2009 